University of Wollongong

Research Online

Faculty of Engineering and Information

Faculty of Engineering and Information

Sciences - Papers: Part A

Sciences

$1-1-2017$

Performance evaluation of high strength concrete and steel fibre high strength concrete columns reinforced with GFRP bars and helices

Hayder Alaa Hasan

University of Wollongong, hah966@uowmail.edu.au

M Neaz Sheikh

University of Wollongong, msheikh@uow.edu.au

Muhammad N. S Hadi

University of Wollongong, mhadi@uow.edu.au

Follow this and additional works at: https://ro.uow.edu.au/eispapers

Part of the Engineering Commons, and the Science and Technology Studies Commons

Research Online is the open access institutional repository for the University of Wollongong. For further information contact the UOW Library: research-pubs@uow.edu.au 


\title{
Performance evaluation of high strength concrete and steel fibre high strength concrete columns reinforced with GFRP bars and helices
}

\author{
Abstract \\ This study presents the results of an experimental investigation on high strength concrete (HSC) and \\ steel fibre high strength concrete (SFHSC) circular column specimens reinforced longitudinally and \\ transversely with Glass Fibre-Reinforced Polymer (GFRP) bars and helices, respectively. The Influence of \\ the type of the reinforcement (steel and GFRP), the pitch of the transverse reinforcement, the addition of \\ the steel fibres and the loading condition (concentric, eccentric and four-point loading) on the \\ performance of the specimens was investigated. The study showed that the GFRP bar reinforced HSC \\ (GFRP-HSC) specimen is as efficient as the steel bar reinforced HSC (steel-HSC) specimen in sustaining \\ concentric axial load. However, the maximum load sustained by the GFRP-HSC specimens under \\ eccentric axial load was $10-12 \%$ lower than the maximum load sustained by the steel-HSC specimens. \\ GFRP bar reinforced SFHSC (GFRP-SFHSC) specimens sustained 3-13\% higher axial load and 14-27\% \\ greater ductility than GFRP-HSC specimens under different loading conditions. Furthermore, reducing the \\ pitch of the GFRP helices in GFRP-SFHSC specimens resulted in a significant improvement in the ductility \\ and the post-peak axial load-axial deformation behaviour of the specimens.

\section{Disciplines} \\ Engineering | Science and Technology Studies

\section{Publication Details} \\ Hasan, H., Sheikh, M. \& Hadi, M. N S. (2017). Performance evaluation of high strength concrete and steel \\ fibre high strength concrete columns reinforced with GFRP bars and helices. Construction and Building \\ Materials, 134 297-310.
}




\title{
Performance Evaluation of High Strength Concrete and Steel Fibre High Strength Concrete Columns Reinforced with GFRP Bars and Helices
}

\author{
Hayder Alaa Hasan ${ }^{1}$ \\ ${ }^{1}$ Ph.D. Candidate, School of CME Engineering, University of Wollongong, Australia. \\ Email: hah966@uowmail.edu.au \\ M. Neaz Sheikh ${ }^{2}$ \\ ${ }^{2}$ Senior Lecturer, School of CME Engineering, University of Wollongong, Australia. \\ Email: msheikh@uowmail.edu.au
Muhammad N. S. Hadi ${ }^{3, *}$
${ }^{3}$ Associate Professor, School of CME Engineering, University of Wollongong, Australia. Email: mhadi@uow.edu.au, *Corresponding author

\section{Abstract}

This study presents the results of an experimental investigation on high strength concrete (HSC) and steel fibre high strength concrete (SFHSC) circular column specimens reinforced longitudinally and transversely with Glass Fibre-Reinforced Polymer (GFRP) bars and helices, respectively. The Influence of the type of the reinforcement (steel and GFRP), the pitch of the transverse reinforcement, the addition of the steel fibres and the loading condition (concentric, eccentric and four-point loading) on the performance of the specimens was investigated. The study showed that the GFRP bar reinforced HSC (GFRP-HSC) specimen is as efficient as the steel bar reinforced HSC (steel-HSC) specimen in sustaining concentric axial load. However, the maximum load sustained by the GFRP-HSC specimens under eccentric axial load was 10-12\% lower than the maximum load sustained by the steel-HSC specimens. GFRP bar reinforced SFHSC (GFRP-SFHSC) specimens sustained 3-13\% higher axial load and 14-27\% greater ductility than GFRP-HSC specimens under different loading 
conditions. Furthermore, reducing the pitch of the GFRP helices in GFRP-SFHSC specimens resulted in a significant improvement in the ductility and the post-peak axial load-axial deformation behaviour of the specimens.

\section{Introduction}

31 Fibre-Reinforced Polymer (FRP) reinforcing bars feature many advantageous characteristics such as high tensile strength, high durability, light weight and resistance to harsh environmental conditions. These features make the FRP reinforcing bars ideal replacements for the conventional steel bars in reinforcing concrete structures that require such features. Investigation on the structural behaviour of FRP bar reinforced concrete members became the major objective of many recent studies. The flexural behaviour of FRP bar reinforced normal and high strength concrete members were extensively investigated in the last two decades [1, 2]. These studies significantly contributed in developing guidelines and standards for the design of FRP bar reinforced concrete flexural members. However, the behaviour of FRP

40 bars under compression loads is considered complicated. This is because the 41 nonhomogeneous and anisotropic nature of the FRP bars, which leads to micro-buckling of 42 fibres in the FRP bars under axial compression [3]. Accordingly, The ACI 440.1R-06 [4] does not recommend reinforcing concrete columns longitudinally with FRP bars. The CAN/CSA S806-12 [5] ignores the contribution of FRP bars in the compression zone of both flexural and compression members. Moreover, the ACI 440.1R-15 [6] provides no guidelines for the use of FRP bars in reinforcing compression members. The structural behaviour of

47 FRP reinforced compression members were investigated in few research studies [7-9]. However, these studies were limited to FRP bar reinforced concrete columns cast with normal strength concrete (NSC) with compressive strength lower than $50 \mathrm{MPa}$. Hence, the observations obtained from these studies may not be adequate for FRP bar reinforced HSC 
51 columns, since the behaviour of HSC columns differs significantly from NSC columns [1012]. Given the lack of experimental investigations on HSC compression members reinforced with FRP reinforcement, this study intends to expand the current state of knowledge through experimentally investigating the structural behaviour of HSC columns reinforced longitudinally and transversely with Glass Fibre-Reinforced Polymer (GFRP) bars and helices, respectively. Investigations on the behaviour of Carbon Fibre Reinforced Polymer (CFRP) and Aramid Fibre Reinforced Polymer (AFRP) bar reinforced concrete columns are considered beyond the scope of this paper.

60 The majority of the experimental results reported in the previous studies on the behaviour of

61 FRP bar reinforced NSC columns [13-15] were based on columns tested under concentric axial load. Only few studies provided experimental data from columns tested under eccentric axial load [16-17]. In fact, concrete columns are usually subjected to a combination of concentric axial load and bending moment rather than a pure concentric axial load. Hence, this study investigates the effect of different loading conditions (concentric and eccentric axial load as well as four-point loading) on the behaviour of GFRP bar reinforced HSC columns (GFRP-HSC).

69 The other focus of this study is to investigate the effect of adding steel fibres to the GFRP bar 70 reinforced HSC (GFRP-HSC) columns. The main objective of the addition of steel fibres is to 71 overcome the lack of ductility that might be experienced by the GFRP-HSC columns, where 72 both HSC and GFRP bars are brittle compared to the NSC and conventional steel bars, respectively. In addition, steel fibres may improve the post-peak behaviour of GFRP-HSC columns and thus providing adequate warning before the failure of GFRP-HSC columns. 
Hence, the behaviour of GFRP bar reinforced steel fibre high strength concrete (GFRP-

SFHSC) column is also investigated in this study.

\section{Experimental Program}

\subsection{Specimen Design and Preparation}

80 The experimental tests consisted of 16 circular column specimens of $210 \mathrm{~mm}$ diameter and $800 \mathrm{~mm}$ height. The specimens were divided into four groups with four specimens in each group. The specimens in the first group (Group S60) were prepared as reference specimens for comparison purposes. The Group S60 specimens were reinforced in the longitudinal direction with six N12 (deformed steel bars with $12 \mathrm{~mm}$ diameter) and transversely with R10 (rounded steel bars with $10 \mathrm{~mm}$ diameter) helices with $60 \mathrm{~mm}$ pitch. Group S60 specimens satisfy the requirements of ACI 318-14 [18]. The specimens in the second group (Group G60) were reinforced with six \#4 (nominal diameter = $12.7 \mathrm{~mm}$ ) GFRP bars in the longitudinal direction and transversely with \#3 (nominal diameter $=9.5 \mathrm{~mm}$ ) GFRP helices with a pitch of $60 \mathrm{~mm}$. The specimens in this group were designed to investigate the effect of the direct replacement of steel reinforcement with the same amount of GFRP reinforcement on the

91 behaviour of HSC columns. The specimens in the third group (Group G60F) were also reinforced with six \#4 GFRP bars and with \#3 GFRP helices with $60 \mathrm{~mm}$ pitch in the longitudinal and transverse directions, respectively. In addition, steel fibres with volumetric

94 ratio $\left(v_{f}\right)$ of $1 \%$ were added to the HSC mix used in casting the specimens in Group G60F. The specimens in this group were designed to investigate the effect of the addition of steel fibres on the behaviour of GFRP bar reinforced high strength concrete (GFRP-HSC) columns.

97 The specimens in the fourth group (Group G30F) were reinforced longitudinally with six \#4

98 GFRP bars and transversely with \#3 GFRP helices with $30 \mathrm{~mm}$ pitch. As in Group G60F,

99 steel fibres of $1 \%$ (by volume) were added to the HSC mix used in casting the specimens in 
100 Group G30F. The specimens in this group were designed to study the combined effect of the

101 pitch of GFRP transverse reinforcement and the addition of steel fibre on the strength and

102 ductility of GFRP bar reinforced HSC columns. The test matrix of the specimens is presented

103 in Table 1. The dimensions and reinforcement configurations of the specimens are shown in

104 Fig. 1.

105

106 The first specimen of each group was concentrically loaded. The second and the third

107 specimens of each group were tested under eccentric axial load with eccentricities of $25 \mathrm{~mm}$

108 and $50 \mathrm{~mm}$, respectively. The fourth specimen of each group was tested as beam under four-

109 point loading in order to assess the pure flexural behaviour of the specimens. The loading

110 conditions used in this study (including the 25 and $50 \mathrm{~mm}$ eccentric axial loads) were

111 selected based on the testing facilities available at the University of Wollongong, Australia.

112

113 The specimens are labelled by a series of letters and numbers corresponding to the

114 reinforcement type, configuration of the transverse reinforcement, loading conditions and the

115 presence of the steel fibres (Table 1). The first letter in each specimen label refers to the

116 reinforcement material, where "S" refers to steel reinforcement and "G" refers to GFRP

117 reinforcement. The first number in each specimen label refers to the pitch of the helices. The

118 second letter "E" and the second number in each specimen label stand for the loading

119 condition: E0 refers to concentric load; E25 and E50 refer to axial loads with $25 \mathrm{~mm}$ and 50

120 mm eccentricity, respectively. The letter "B" refers to the four-point loading. The letter "F"

121 stands for the presence of steel fibres. For example, Specimen G60E50F is reinforced

122 longitudinally with GFRP bars (6\#4) and transversely with GFRP helix with a pitch of 60

$123 \mathrm{~mm}$ and tested under $50 \mathrm{~mm}$ eccentric axial load. Besides, 1\% (by volume) steel fibres were

124 added to the concrete mix of this column specimen. 


\subsection{Fabrication and Instrumentation of the tested specimens}

126 Polyvinyl chloride (PVC) pipes with an inner diameter of $210 \mathrm{~mm}$ and a height of $800 \mathrm{~mm}$

127 were used as moulds to cast the specimens. Also, a wooden frame was used to hold the PVC 128 pipes vertically and to prevent any movement during the casting of the specimens. Steel and

129 GFRP reinforcement cages were assembled based on the reinforcement arrangement of each

130 specimen. First, the longitudinal steel and GFRP bars were aligned vertically using two 131 plastic templates with an outer diameter of $150 \mathrm{~mm}$ (Fig 2a). The plastic templates have 12

132 holes distributed evenly around the perimeter of the templates: six of the holes fit the steel

133 bars and the other six holes fit the GFRP bars. Afterwards, the longitudinal bars were 134 assembled with the reinforcing helices using steel wire ties. The helices were adjusted to have 135 the required pitch using two aluminium spacer jigs having groves at $30 \mathrm{~mm}$ centres (Fig. $2 \mathrm{~b}$ ).

136 The groves were used for helices with $30 \mathrm{~mm}$ pitch and every second grove for helices with

$13760 \mathrm{~mm}$ pitch. Afterwards, the completed reinforcement cages (Fig. 2c) were placed inside the

138 PVC moulds as shown in Fig. 2d. The steel and GFRP helices were fabricated to have an 139 outer diameter of $170 \mathrm{~mm}$. the concrete cover at the sides of the specimens was $20 \mathrm{~mm}$. Also

140 the steel and GFRP longitudinal bars were cut in lengths of $760 \mathrm{~mm}$ to ensure a constant 141 concrete cover of $20 \mathrm{~mm}$ at the top and the bottom of the specimen.

143 All the specimens were cast on the same day at the laboratory of the School of Civil, Mining

144 and Environmental Engineering, University of Wollongong, Australia. Ready mix high 145 strength concrete with a maximum aggregate size of $10 \mathrm{~mm}$ provided by Hanson Company, 146 Australia [19] was used. The HSC mix was poured directly from the truck mixer into the 147 moulds prepared for Groups S60 and G60 specimens. For the rest of the specimens (Groups 148 G60F and G30F specimens), steel fibres were added to the concrete mix using a concrete 149 mixer. Firstly, the ready mix HSC was placed into the concrete mixer and then steel fibres 
150 were added gradually and were dispersed uniformly using a sieve and were mixed for about 15110 minutes. Afterwards, the concrete mix was poured into the moulds prepared for Group

152 G60F and Group G30F specimens. The specimens were cast vertically in three stages. In 153 every stage the concrete was internally vibrated to remove air voids and to ensure perfect 154 compaction. During the following 28 days, the specimens were kept in the moulds and wet 155 hessian was used to cure the specimens. Meanwhile, plastic sheets were used to cover the specimens and to maintain the moisture conditions.

\subsection{Materials}

159 The mix proportions of the high strength concrete (HSC) used in casting the specimens are

160 presented in Table 2. The average 28-day compressive strength of the nonfibrous and fibrous 161 concrete was 85 and $93 \mathrm{MPa}$, respectively. Two different sizes of steel bars were used in 162 reinforcing Steel-HSC column specimens: $12 \mathrm{~mm}$ deformed steel bars N12 (longitudinal 163 reinforcement), and $10 \mathrm{~mm}$ plain mild rounded steel bars R10 (transverse reinforcement). The 164 mechanical properties of the N12 and R10 steel bars were determined according to AS 13911652007 [20] as shown in Table 3. The GFRP bars and the GFRP helices used in reinforcing the 166 GFRP bar reinforced specimens were sand-coated to improve the bond between the concrete 167 and the embedded GFRP bars. Sand-coated \#4 GFRP bars and sand-coated \#3 GFRP helices 168 were used as longitudinal reinforcement and transverse reinforcement, respectively. Both \#4 169 GFRP longitudinal bars and \#3 GFRP helices were provided by V-Rod Company, Australia 170 [21]. In addition to the standard nominal diameter and the cross-sectional area of the GFRP 171 bars provided by V-Rod company, the diameter and the cross-sectional area of the GFRP bars 172 were also obtained using the immersion test according to ISO 104061-1:2015 [22], as

173 presented in Table 4. The mechanical properties of the GFRP bars were determined according 174 to ASTM D7205-11 [23] (Table 4). The steel fibres were provided by Ganzhou Daye 
175 Metallic Fibres Company, China [24]. The steel fibres used in this study were straight in 176 shape with brass coated surface. The steel fibres used were $13 \mathrm{~mm}$ in length $(l)$ and $0.2 \mathrm{~mm}$

177 in diameter $(d)$ with an aspect ratio $(l / d)$ of 65 . The ultimate tensile strength of the steel 178 fibres was $2500 \mathrm{MPa}[24]$.

\subsection{Test Setup}

181 Before testing, the top and the bottom parts of each specimen were externally wrapped with

182 two layers of CFRP sheets to ensure that failure would occur at the mid-height of the 183 specimen. The thickness and the width of CFRP sheets were $0.5 \mathrm{~mm}$ and $100 \mathrm{~mm}$, 184 respectively. Besides, the top and the bottom ends of each specimen were caped with a thin layer of high strength plaster to ensure a uniform distribution of the applied axial load during the test. All specimens were tested using the Denison testing machine having maximum compressive load capacity of $5 \mathrm{MN}$. Two loading heads fabricated at the University of

188 Wollongong, Australia were used at the top and the bottom ends of each specimen to apply

189 the axial loads at the required eccentricity. Each loading head consisted of circular steel plate and steel ball joint (Fig. 3a). For the eccentrically loaded specimens, the steel ball joints were used to transfer the applied load of the testing machine into $25 \mathrm{~mm}$ and $50 \mathrm{~mm}$ eccentric axial loads. For concentrically loaded specimens, the steel ball joints were not used and the applied

193 load of the testing machine was transferred concentrically to the specimen directly through

194 the circular steel plates. The circular steel plates were used to protect the ends of the specimens from the bearing failure (crushing of the ends of the specimens). The inner diameter of the circular steel plates was larger than the diameter of the tested specimens.

197 Hence, the circular steel plates provided no restraint to the ends of the specimens during the

198 test. For specimens tested as beams, a four-point loading system consisted of two steel

199 circular rigs was used. The beam specimens were tested over a clear span of $700 \mathrm{~mm}$ and the 
200 distance between the two-point loads was kept constant at $233.3 \mathrm{~mm}$ (Fig 3b). A typical test setup of the column and the beam specimens is shown in Fig. 4.

202

Two linear variable differential transducers (LVDTs) were attached vertically to the heads of the testing machine at two opposite corners to measure the axial deformation in the column specimens during the test. For specimens tested under eccentric loads, a laser triangulation was placed at the mid-height of the specimen to capture the lateral deformation. For specimens tested as beams, the laser triangulation was fixed underneath a hole at midspan of the testing rig to measure the midspan deflection of the tested specimens.

210 At the beginning of the test, the specimens were loaded (force controlled) at the rate of $2 \mathrm{kN} / \mathrm{s}$ to $100 \mathrm{kN}$ and then the specimens were unloaded to $20 \mathrm{kN}$ at the same rate to prevent any movements in the specimens that might occur during the test. Afterwards, the specimens were reloaded (displacement-control) at the rate of $0.005 \mathrm{~mm} / \mathrm{s}$ until the failure (specimens

214 experienced a substantial or total loss of the strength) of the specimens. The LVDTs and the

215 laser triangulation were connected to a data logger to capture the data at every $2 \mathrm{~s}$. The applied axial load was recorded during the testing of the specimens via the internal load cell

217 of the Denison testing machine.

\section{3. Experimental Results and Analysis}

\subsection{General Observations}

221 All column specimens were tested until failure. Two main points were noted in the loaddeformation curve of the tested specimens: the first peak load $\left(P_{\text {Peak 1 }}\right)$ and the second peak

223 load $\left(P_{\text {Peak 2 }}\right)$ as shown in Fig 5. The $P_{\text {Peak 1 }}$ represents the maximum axial load sustained 224 by the gross area of the specimen (the area of the reinforced concrete core plus the area of 
concrete cover of the specimen, $A_{g}$ ), while the $P_{\text {Peak } 2}$ represents the maximum axial load

226 sustained by the confined concrete core $\left(A_{c c}\right)$ of the specimen after the loss of the concrete

227 cover. Under concentric axial load, Specimens S60E0, G60E0 and G60E0F (reinforced transversely with steel or GFRP helices having a pitch of $60 \mathrm{~mm}$ ) exhibited no second peak load due to the low confinement pressure provided by the transverse helices. In contrast, the well-confined Specimen G30E0F (reinforced transversely with GFRP helix having a pitch of $30 \mathrm{~mm}$ ) exhibited a second peak load greater than the first peak load due to the adequate confinement pressure provided by the closely spaced GFRP helix. Besides, the $30 \mathrm{~mm}$ pitch GFRP helix in Specimen G30E0F contributed in delaying the crack propagation of the concrete core, restraining the GFRP longitudinal bars against buckling and allowing the specimen to fail progressively. On the other hand, all the eccentrically loaded specimens did not experience a well-defined second peak load, even specimens reinforced transversely with GFRP helices with a pitch of $30 \mathrm{~mm}$ due the effect of the combined loading (axial load and bending moment). The steel bar reinforced Specimen S60B tested under four-point loading also showed one peak load. However, all the GFRP bar reinforced specimens tested under four-point loading showed a second peak load due to the elastic linear stress-strain relationship and the high tensile strength of the GFRP bars and the GFRP helices compared to the steel bars and steel helices.

In general, the axial load-axial deformation and the axial load-lateral deformation behaviour of all tested specimens experienced three phases as shown in Fig. 5. The first phase (Phase 1) represents the ascending part of the load-deformation curve up to the first peak load $\left(P_{\text {Peak } 1}\right)$.

247 During this phase, the transverse reinforcement and the steel fibres had no or insignificant 248 effects on the behaviour of the specimens. The second phase (Phase 2) represents the drop in the total axial load due to the spalling of the concrete cover after the $P_{P e a k 1}$. The third phase 
250 (Phase 3) represents the part of the load-deformation behaviour of the specimen that starts after the spalling of the concrete cover (activation of the transverse reinforcement) and ended with the total failure of the specimen. The load-deformation behaviour of the specimen during Phase 3 is governed by the type of the longitudinal and transverse reinforcement (steel or GFRP), the pitch of the transverse helices and the presence of the steel fibres.

The ductility (energy absorption capability) of the tested specimens was determined based on the area under the axial load-axial deformation curve of the specimens as outlined in ASTM C1018-97 [25]. Ductility index $\left(I_{5}\right)$ was used as a measure for the ductility of the specimen

(Fig. 5). The $I_{5}$ represents the ratio between the area ABDE (area under the axial load-axial deformation curve up to $3 \delta_{y}$ ) to the area $\mathrm{ABC}$ (area under the axial load-axial deformation curve up to $\delta_{y}$ ). Where $\delta_{y}$ is the yield deformation (the deformation at which the first crack occurs). The $\delta_{y}$ corresponds to the intersection point between the horizontal line drawn from the $P_{P e a k 1}$ and the straight line passes the origin and the point representing the 0.75 times the $P_{\text {Peak } 1}$ [26], as shown in Fig. 5.

\subsection{Failure modes of the tested specimens}

267 The failure modes of the column specimens are shown in Fig 6. The reinforcement material

268 (steel or GFRP), reinforcement arrangements, presence of the steel fibres and the loading 269 condition were the main parameters that influenced the failure modes of the tested specimens.

270 For concentrically loaded specimens, Specimens S60E0 and G60E0 exhibited spalling of the 271 concrete cover immediately after reaching the $P_{\text {Peak } 1}$. The spalling of the concrete cover was 272 mainly observed at the mid-height of the tested specimens and was attributed to the tendency 273 of the concrete cover to buckle away from the concrete core when subjected to concentric 274 axial load. Similar observations have been made in a number of experimental studies (Paultre 

experienced cracks in the concrete cover at $P_{\text {Peak } 1}$, the concrete cover remained intact and

277 attached to the concrete core throughout the test, even beyond the $P_{\text {Peak } 1}$. At the end of the 278 test, the nonfibrous Specimens S60E0 and G60E0 experienced spalling of almost the entire 279 concrete cover, whereas, only limited spalling of the concrete cover was observed in the 280 fibrous Specimens G60E0F and G30E0F (Fig. 6). The failure of the Specimens S60E0 and 281 G60E0 was initiated by the buckling of the longitudinal steel and GFRP bars, respectively, and failed by the rupture of the steel and GFRP helices, respectively. However, the failure of

283 Specimens G60E0F and G30E0F was mainly due to the rupture of the GFRP helices which 284 occurred after the crushing of the concrete core. Figs. $7 \mathrm{a}$ and $7 \mathrm{~b}$ show the buckling of the steel and GFRP longitudinal bars and the rupture of the steel and GFRP helices of Specimens S60E0 and G60E0, respectively. Figs. 7c and 7d show the rupture of the GFRP helices of Specimens G60E0F and G30E0F at the end of the test after removing the concrete cover from the specimens by hand.

290 For eccentrically loaded specimens, the first sign of the failure of all specimens was the crushing of the concrete in the compression face of the specimens accompanied by transverse cracks in the tension face. This behaviour was due to the combined axial-flexural loading which was attributed to the change in the loading condition at the ends of the tested

294 specimens from concentric axial load to $25 \mathrm{~mm}$ or $50 \mathrm{~mm}$ eccentric axial loads. Afterwards, 295 the reference Specimens S60E25 and S60E50 exhibited buckling of the longitudinal steel bars located in the extreme compression layer. At the latter stage, the reference Specimens S60E25 and S60E50 failed due to the rupture of the longitudinal steel bars located in the extreme tension layer. On the other hand, Specimen G60E25 failed due to the rupture of the longitudinal GFRP bars and GFRP helices at the middle part of the compression face of the 
300 specimen. It was observed that the rupture of the GFRP longitudinal bars located in the 301 compression region of Specimen G60E25 could not be prevented due to the insufficient 302 confinement provided by the GFRP helices. The failure of Specimen G60E50 was due to the 303 rupture of the GFRP helices that occurred in the top third part of the specimen. Similarly, the

304 failure of Specimens G60E25F, G30E25F, G60E50F and G30E50 was attributed to the 305 rupture of the GFRP helices at the compression face of the specimens.

307 For specimens tested under four-point loading, the number and the width of the cracks 308 experienced by the specimens at failure were depended mainly on the pitch of the transverse 309 helices. Figure 8 presents a close-up view of the crushed region of the specimens tested as

310 beams. Specimen G30BF exhibited a larger number of closely spaced cracks compared to 311 Specimens S60B, G60B and G60BF. The crack width of the reference Specimen S60B at 312 failure was about $22 \mathrm{~mm}$ which was about $13 \%$ smaller than the crack width of Specimen 313 G60B and about 9\% larger than the crack width of Specimen G60BF. The crack width of 314 Specimen G30BF was about $5 \mathrm{~mm}$. Similar to the eccentrically loaded specimens, the failure 315 of all specimens tested under four-point loading started with the crushing of the concrete in 316 the compression face at midspan of the specimens. Finally, the rupture of the longitudinal 317 steel bars in the extreme tension layer at midspan resulted in the failure of Specimen S60B, 318 whereas the rupture of the GFRP helices at midspan resulted in the total collapse of the 319 Specimens G60B, G60BF and G30BF.

\subsection{Behaviour of concentrically loaded specimens}

322 Four specimens (the first specimen in each group) were tested under concentric axial load.

323 Fig. 9 presents the axial load-axial deformation behaviour of the concentrically loaded 324 specimens (S60E0, G60E0, G60E0F and G30E0F). The ascending part of the axial load-axial 

patterns up to the first peak load $P_{\text {Peak } 1}$ and was mainly governed by the compressive strength of the concrete. This is because the lateral confinement provided by the transverse reinforcement (steel or GFRP helices) had little or no effect up to the first peak load due to the relatively low lateral dilation of the concrete. Similar observations were reported in

330 Cusson and Paultre (1994) [10] and in Paultre et al. (2010) [29] for the steel bar reinforced

331 HSC and SFHSC columns, respectively, and in Afifi et al. (2015) [15] for the GFRP bar reinforced concrete columns. The concrete cover of the concentrically loaded specimens did not crack until the specimens reached about $95 \%$ of the first peak load, where hairline cracks began to appear. With further loading, the hairline cracks widened and developed into vertical cracks. The maximum axial load sustained by the reference Specimen S60E0 was $2735 \mathrm{kN}$, which was about $0.5 \%$ higher than the maximum axial load of Specimen G60E0. Although the direct replacement of the steel reinforcement with the same amount of GFRP reinforcement resulted in a reduction in the maximum axial load carrying capacity of the columns $[17,30]$, Specimen G60E0F sustained about 2\% higher axial load than the reference

340 Specimen S60E0. The higher axial load sustained by Specimen G60E0F was attributed to the presence of the steel fibre which led to an increase in the compressive strength of the concrete by restraining the formation of the cracks and thereby increasing the axial load of the specimen. Specimen G30E0F sustained about 9\% higher first peak load $\left(P_{\text {Peak } 1}\right)$ than the reference Specimen S60E0.

346 After the first peak load $\left(P_{\text {Peak } 1}\right)$, all specimens exhibited a drop in the axial load carrying 347 capacity varied between 5 to $20 \%$ of the load at the $P_{P e a k 1}$ due to the spalling of the 348 concrete cover. After the concrete cover spalled off, the concrete core experienced a lateral 349 expansion, which activated the passive confining pressure of the steel and GFRP helices. 
350 Afterwards, the concrete core started gaining strength whilst the concrete cover gradually spalled off for nonfibrous Specimens (S60E0 and G60E0) and disintegrates for the fibrous Specimens (G60E0F and G30E0F). Specimens S60E0 and G60E0 showed only $P_{\text {Peak } 1 .}$. Besides, the nonfibrous Specimens S60E0 and G60E0 experienced a significant loss of about $45 \%$ and $50 \%$ of their total axial load carrying capacity no longer after the spalling of the concrete due to the rupture of the steel and the GFRP helices, respectively. The rupture of the steel helix of Specimen S60E0 occurred at an axial deformation of about $4.4 \mathrm{~mm}$, whereas the rupture of the GFRP helix of Specimen G60E0 occurred at an axial deformation of about $3.5 \mathrm{~mm}$. Similarly, Specimen G60E0F showed only $P_{\text {Peak } 1}$, however, due to the presence of the steel fibers Specimen G60E0F showed a gradual decrease in the total axial load carrying capacity until the specimen failed at an axial deformation of about $7.8 \mathrm{~mm}$. On the other hand, Specimen G30E0F reached a second peak load $\left(P_{\text {Peak } 2}\right)$ of about $10 \%$ higher than the $P_{\text {Peak 1 }}$. The second peak load $\left(P_{\text {Peak } 2}\right)$ was an indication of the effectively combined confinement provided by both closely spaced GFRP helix and steel fibres. Specimen G30E0F failed due to the rupture of the GFRP helix at an axial deformation of about $12.6 \mathrm{~mm}$.

The direct replacement of the steel reinforcement in (Specimen S60E0) by same amount of

367 GFRP reinforcement in (Specimen G60E0) resulted in about 30\% less ductility in the HSC column. Despite the brittle nature of both HSC and GFRP bars, the ductility of the Specimens

369 G60E0F was only 10\% lower than the reference specimen S60E0. Reducing the pitch of the 370 GFRP helix from $60 \mathrm{~mm}$ to $30 \mathrm{~mm}$ in Specimen G30E0F resulted in about 38\% higher ductility compared to Specimen S60E0, as shown in Table 5. 


\subsection{Behaviour of eccentrically loaded specimens}

374 Eight specimens were tested under eccentric axial load: four specimens (S60E25, G60E25, 375 G60E25F and G30E25F) were tested under $25 \mathrm{~mm}$ eccentric axial load and four specimens 376 (S60E50, G60E50, G60E50F and G30E50F) were tested under $50 \mathrm{~mm}$ eccentric axial load. In

377 general, all specimens tested under eccentric axial load showed one peak load $\left(P_{P e a k ~ 1}\right)$, even 378 for specimens reinforced transversely with $30 \mathrm{~mm}$ GFRP helices. The decrease in the confinement efficiency of the GFRP helices in the GFRP bar reinforced specimens was attributed to the change in the loading condition at the ends of the specimens from concentric axial load to $25 \mathrm{~mm}$ or $50 \mathrm{~mm}$ eccentric axial loads.

382

383 Figure 10a presents the axial load versus axial deformation behaviour of the specimens tested under $25 \mathrm{~mm}$ eccentric axial load. The axial load versus lateral deformation behaviour of the specimens is also presented in Fig 10a. The ascending part of the load deformation curve of the specimens tested under $25 \mathrm{~mm}$ eccentric axial load was almost linear until the concrete cover started to spall off. This was an indication that the confinement provided by the transverse reinforcement and the steel fibres had insignificant effect on the axial load-axial deformation behaviour of the Specimens S60E25, G60E25, G60E25F and G30E25F up to the peak load. Similar observation was also reported in in Paultre et al. [29] and in Hsu and Hsu [31]. Specimen S60E25 sustained maximum axial load of $1771 \mathrm{kN}$. The maximum axial load sustained by Specimen G60E25 was 1599 , which was approximately $10 \%$ less than the axial

393 load sustained by the reference Specimen S60E25. The ductility of Specimen G60E25 was only 3\% lower than the ductility of the reference Specimen S60E25 due to the high tensile strength of the longitudinal GFRP bars which contributed in increasing the ductility of

396 Specimen G60E25 as the load eccentricity increased to $25 \mathrm{~mm}$. Similar to the concentrically

397 loaded specimens, Specimen G60E25F sustained a slightly higher axial load (about 1.25\%) 

and $24 \%$ higher than the ductility of Specimen S60E25 and G60E25, respectively. This was an indication on the effect of the steel fibres on the ductility of the specimens. Reducing the pitch of the GFRP helix in Specimens G30E25F did not increase the axial load sustained by

402 the specimen. This is because the closely spaced GFRP helix caused a separation plane

403 between the concrete core and the surrounding concrete cover, which led to early spalling 404 (instability failure) of the concrete cover. Similar observations were also reported in Razvi and Saatcioglu [32] and in Pessiki and Pieroni [33]. However, reducing the pitch of the GFRP helix in Specimen G30E25F enhanced the post-peak behaviour, where specimen G30E25F sustained an almost constant axial load of about $94 \%$ of the maximum axial load until failure. Moreover, the ductility of Specimen G30E25F increased by about $40 \%, 44 \%$ and $17 \%$ compared to Specimens S60E25, G60E25 and G60E25F, respectively.

411 In comparison with the concentrically loaded specimens, GFRP bar reinforced HSC 412 specimens in Group G60 experienced a reduction of $41 \%$ in the axial load carrying capacity 413 due to increasing the eccentricity of the applied load from zero (concentric axial load) to 25 $414 \mathrm{~mm}$ eccentric axial load. This reduction was about $6 \%$ greater than the reduction in the axial 415 load carrying capacity experienced by the steel bar reinforced HSC specimens in Group S60. 416 However, the reduction in the axial load carrying capacity of the GFRP bar reinforced 417 SFHSC specimens in group G60F was almost similar to the reduction in the axial load 418 carrying capacity of the steel bar reinforced HSC specimens (Group S60).

420 Figure $10 \mathrm{~b}$ shows the axial load-axial deformation and axial load-lateral deformation 421 behaviour of the specimens tested under $50 \mathrm{~mm}$ eccentric axial load. Similar to the specimens 422 tested under $25 \mathrm{~mm}$ eccentric axial load, the behaviour of Specimens S60E50, G60E50, 
423 G60E50F and G30E50F throughout the ascending part of their axial load-axial deformation

424 curves was slightly influenced by the confinement provided by the helices and the steel fibres.

425 The axial load sustained by the reference Specimen S60E50 was 1158 kN. Specimen G60E50

426 sustained about $12 \%$ lower axial load than the reference Specimen S60E50. However,

427 Specimen G60E50 achieved about 11\% higher ductility than Specimen S60E50, as the load

428 eccentricity increased to $50 \mathrm{~mm}$. Specimens G60E50F achieved about $0.6 \%$ and $14 \%$ higher

429 axial load and $25 \%$ and $13 \%$ higher ductility in comparison with the axial load and the

430 ductility of the Specimen S60E50 and G60E50, respectively. Similar to Specimen G30E25F,

431 Specimen G30E50F achieved 10\% lower axial load compared to the reference Specimen

432 S60E50 due to the early spalling of the concrete cover. However, due to the combined effect

433 of the closely spaced transverse GFRP helix and the steel fibres, the ductility of the Specimen

434 G30E50F was about 35\% higher than the reference Specimen S60E50.

435

436 It was found that the reduction in the axial load carrying capacity experienced by the steel bar

437 reinforced HSC specimens of Group S60 due to increasing the loading eccentricity to $50 \mathrm{~mm}$

438 was about $58 \%$, whereas the reduction in the axial load carrying capacity exhibited by the

439 GFRP bar reinforced HSC specimens in Groups G60, under the same loading eccentricity,

440 was about 62\%. The GFRP bar reinforced SFHSC specimens in Group G60F and Group

441 G30F experienced about 58\% and 65\% reduction in the axial load carrying capacity,

442 respectively.

444 It was observed that under concentric axial load, the axial load carrying capacity of the GFRP

445 bar reinforced HSC Specimen G60E0 in Group G60 was almost similar to the axial load of

446 the reference Specimen S60E0 in Group S60, which was reinforced with the same amount of

447 steel longitudinal bars and helices. However, the efficiency of the GFRP bar reinforced HSC 
448 specimens in sustaining axial load decreased with increasing the loading eccentricity, where 449 under $25 \mathrm{~mm}$ and $50 \mathrm{~mm}$ eccentric axial load, Specimens G60E25 and G60E50 in Group G60 sustained 10 and $12 \%$ lower axial load compared to the reference steel bar reinforced HSC Specimens S60E25 and S60E50 in Group S60. On the other hand, the axial load carrying capacity of the specimen in Group G60F was slightly greater than the axial load carrying capacity of the specimen in Group S60 under concentric axial loads. Under eccentric axial loads (combined axial load and bending moment), the specimens in Group G60F experienced a reduction in the axial load carrying capacity due to the combined stresses in the crosssection of the specimens. However, the axial load carrying capacity of the eccentrically loaded specimens in Group G60F was still greater than the axial load carrying capacity of the eccentrically loaded specimens in Group S60. Table 6 reports the experimental results (peak loads, corresponding deformations and ductility) of the specimens tested under $25 \mathrm{~mm}$ and 50 mm eccentric axial loads.

\subsection{Behaviour of specimens tested under four-point loading}

463 Four specimens (S60B, G60B, G60BF and G30BF) were tested as beam under four-point 464 loading to explore the behaviour of the specimens under pure flexural load. Fig. 11 shows the load-midspan deflection behaviour of the tested specimens. Table 7 presents the experimental results of the tested specimens. Two layers of CFRP sheets were used to wrap the shear span

467 of the GFRP bar reinforced Specimens G60B, G60BF and G30BF to reduce the effect of the 468 shear-induced deflection at midspan and to prevent the shear failure, which might occur 469 because of the small span-to-depth ratio of the tested specimens as well as the high tensile strength of the longitudinal GFRP bars. The shear span of the reference Specimen S60B was also wrapped with CFRP sheets to achieve a consistent comparison. The steel bar reinforced specimen S60B experienced only first peak load, whereas all the GFRP bar reinforced 
473 specimens experienced two peak loads. All specimens tested under four-point loading 474 experienced a linear ascending behaviour up to the first peak load. The reference Specimen 475 S60B sustained load of $309 \mathrm{kN}$ at the first peak. Specimens G60B, G60BF and G30BF 476 sustained about 4, 17 and 19\% higher load, respectively, than the reference specimen S60B.

477 Afterwards, Specimens S60B and G60B experienced a drop in the load carrying capacity of 478 about $13 \%$ and $6 \%$, respectively, due to the crushing of the concrete cover at the compression 479 face of the specimens. However, Specimens G60BF and G30BF experienced no drop in the 480 load carrying capacity due to the presence of the steel fibres. In the post-peak part of the load481 midspan deflection behaviour, the reference Specimen S60B showed no clear second peak 482 load, as mentioned above, and carried an almost constant load of about $75 \%$ of the first peak 483 load until failure. But, Specimens G60B, G60BF and G30BF showed a linear ascending post484 peak behaviour until failure reaching a second peak load of about $61 \%, 65 \%$ and $88 \%$ higher 485 than the first peak load, respectively. The ductility of Specimens G60BF and G30BF was about $12,9 \%$ and $40 \%$ higher than the ductility of the reference specimen S60B, respectively.

\section{Axial load-bending moment interaction diagrams}

489 For designing of the concrete members subjected to different loading conditions (concentric, eccentric and flexural loads), interaction diagrams are plotted for the tested specimens. In this study, four points were used to establish the axial load-bending moment $(P-M)$ diagrams for

492 the experimentally tested specimens in the Groups S60, G60, G60F and G30F. The first point 493 on each $P-M$ diagram represents the concentrically loaded specimens, the second and the third points represent the specimens tested under $25 \mathrm{~mm}$ and $50 \mathrm{~mm}$ eccentric axial loads, respectively, whereas the fourth point represents the specimens tested as beam under fourpoint loading. As most specimens in this study showed no second peak load, the first peak load will be considered the maximum axial load carrying capacity to use for the design 
purposes. Consequently, the first peak load $\left(P_{\text {Peak 1 }}\right)$ experienced by the specimens was used

499 in establishing the interaction diagrams. For the concentrically loaded specimens, the value of

500 the bending moment was taken equal to zero. The bending moment, including the secondary

501 moment for specimens tested under 25 and $50 \mathrm{~mm}$ eccentric axial loads was calculated using

502 Eq. 1, while the bending moment of the specimen tested under four-point loading were 503 calculated using Eq. 2.

$$
M=P_{\text {Peak } 1}(\mathrm{e}+\delta)
$$

505

$$
M=P_{\text {Peak } 1} \mathrm{~L} / 6
$$

where $P_{\text {Peak 1 }}=$ the first peak load of the tested specimens; $\delta=$ the corresponding lateral deformation; $e=$ the load eccentricity and $L=$ the length between the supports of the beam

510 specimens (Fig. 3).

511

512 The experimental axial load-bending moment $(P-M)$ diagrams of the Groups S60, G60,

$513 \mathrm{G} 60 \mathrm{~F}$ and G30F are shown in Fig. 12. It was observed that the axial load and the corresponding bending moment achieved by steel bar reinforced specimens of Group S60 under concentric and eccentric axial load were higher than the axial load and corresponding bending moment of the specimens reinforced with same amount of GFRP reinforcement in

517 Group G60. This is because the elastic modulus of the GFRP bars is lower than the elastic

518 modulus of the steel bars. However, Group G60F specimens experienced higher axial load

519 and moment capacity under concentric, eccentric and flexural loads compared to the Group 520 S60 specimens, which was an indication on the effect of the addition of steel fibres in HSC.

521 The axial load-bending moment diagram of Group G30F was lower than Groups S60 and 522 G60F under eccentric axial load because of the early spalling of the concrete cover that 
523 resulted in lower than expected axial load carrying capacity. However, Specimens G30E0F and G30BF experienced higher axial load and higher bending moment capacity under specimens.

528 The analytical axial load-bending moment interaction diagrams for the GFRP bar reinforced HSC and SFHSC specimens were established to complement the experimental results. The analytical $P-M$ interaction diagrams of the GFRP bar reinforced specimens were developed based on the strain compatibility and the force equilibrium principles adopted for the conventional steel bar reinforced specimens. The CSA A23.3-2014 [34] equivalent rectangular stress block, developed for the steel bar reinforced concrete specimens, was used to predict the axial load carrying capacity and the corresponding bending moment resistances for the GFRP bar reinforced specimens. Two parameters $\alpha_{1}$ and $\beta_{1}$ were used to define the CSA A23.3-2014 [34] equivalent rectangular stress block. The parameters $\alpha_{1}$ and $\beta_{1}$ were calculated using Eq. (3) and Eq. (4), respectively. The GFRP bars were assumed to have a linear elastic stress-strain relationship. Besides, the limiting strain $\varepsilon_{u}$ at the extreme concrete compression layer was taken equal to 0.0035, as prescribed in the CSA A23.3-2014 [34].

$$
\alpha_{1}=0.85-0.0015 f_{c}^{\prime} \geq 0.67
$$

$$
\beta_{1}=0.97-0.0025 f_{c}^{\prime} \geq 0.67
$$

Figure 13 compares the analytical interaction diagrams obtained using the CSA A23.3-2014

546 [34] equivalent rectangular stress block with the experimental data. The comparison indicates

547 that using the equivalent rectangular stress block defined in the CSA A23.3-2014 [34] yielded 
548 reasonable conservative correlations between the computed and the experimentally obtained

549 results. The conservative predictions were attributed to the conservative parameters of the

550 CSA A23.3-2014 [34] equivalent rectangular stress block. Similar observations were also

551 reported in Canbay et al. [12] and in Ozbakkaloglu and Saatcioglu [35] for steel bar

552 reinforced concrete columns under concentric and eccentric axial loads. This was an

553 indication that the response of the GFRP bar reinforced concrete specimens under different

554 loading condition can be reasonably estimated using the same methods adopted for the steel

555 bar reinforced concrete specimens.

556

557 5. Conclusions

558 In this study, 16 specimens were tested under different loading conditions: four specimens under concentric axial load, eight specimens under eccentric axial load and four specimens under four-point loading. The behaviour of the GFRP bar reinforced HSC and SFHSC specimens in regarding to the axial load carrying capacity, failure modes and ductility. Based

562 on the test findings, the following conclusion could be drawn:

563 1. For HSC specimens, the direct replacement of the longitudinal and transverse steel

564 reinforcement with the same amount of GFRP reinforcement did not influence the axial

565 load carrying capacity of the specimen under concentric axial load. However, GFRP bar

566 reinforced HSC specimens experienced about $10 \%$ and $12 \%$ lower axial load carrying

567 capacity than the steel bar reinforced HSC specimens as a result of changing the loading

568 condition from concentric axial load to 25 and $50 \mathrm{~mm}$ eccentric axial load, respectively.

569 2. For SFHSC, it was observed that Group G60F specimens sustained similar or slightly

570 greater axial load than Group S60 specimens under concentric axial loads. The specimens

571 in Group G60F experienced a reduction in the axial load carrying capacity under eccentric

572 axial load (combined axial load and bending moment) due to the combined stresses in the 
cross-section of the specimens. However, the axial load carrying capacity of the eccentrically loaded specimens in Group G60F was still greater than the axial load carrying capacity of the eccentrically loaded specimens in Group S60.

3. Under concentric axial load, only Specimen G30E0F (reinforced transversely with $30 \mathrm{~mm}$ GFRP helix) experienced a second peak load, which was higher than the first peak load. However, all the eccentrically loaded GFRP bar reinforced specimen showed no second peak load even specimens reinforced transversely with $30 \mathrm{~mm}$ GFRP helices due to the change in the loading condition from concentric axial load to $25 \mathrm{~mm}$ or $50 \mathrm{~mm}$ eccentric axial loads. This was an indication that the efficiency of the GFRP transverse reinforcement in confining HSC columns decreases with an increase in the eccentricity of the applied axial load.

4. The failure of the steel bar reinforced specimens was initiated by the buckling of the longitudinal steel bars and then the rupture of the longitudinal steel bars or the steel helix resulted in the total failure of the specimens. The failure of GFRP-HSC was controlled by the rupture of both the longitudinal GFRP bars and the GFRP helices, whereas the failure of the GFRP-SFHSC specimens was mainly attributed to the rupture of the GFRP helices.

5. Under concentric axial load, replacing the steel reinforcement with the same amount of GFRP reinforcement in HSC specimens resulted in about $30 \%$ reduction in the ductility of the specimen. However, under the same loading condition (concentric axial load), GFRP bar reinforced SFHSC specimens experienced almost similar ductility compared to the

594 6. Despite the non-ductile behaviour of HSC and GFRP bars, reducing the pitch of the GFRP helices with the addition of $1 \%$ by volume steel fibres resulted in about $35-40 \%$ higher ductility of Group G30F specimens compared to the reference specimens of group S60 

under different loading conditions. However, closely spaced GFRP helices might lead to 598 an early spalling of the concrete cover.

7. The axial carrying capacity and the bending moment resistances of the GFRP bar 600 reinforced concrete specimens can be reasonably calculated using the equivalent 601 rectangular stress block defined in the CSA A23.3-2014 [34]. This indicates that the 602 response of the GFRP bar reinforced concrete specimens under different loading condition 603 can be predicted using the same analytical procedures used for the steel bar reinforced 604 concrete specimens.

605

606 Acknowledgments

607 The authors express special thanks to the technical officers at the High Bay Laboratories of 608 the University of Wollongong, Australia for their help in conducting the experimental 609 program of this study. Also, the first author would like to acknowledge the Iraqi Government 610 and the University of Wollongong, Australia, for the support of his full $\mathrm{PhD}$ scholarship. The 611 first author thanks his family members for their loving support.

612

\section{References}

614 [1] C. Barris, L. Torres, A. Turon, M. Baena, A. Catalan, An experimental study of the 615 flexural behaviour of GFRP RC beams and comparison with prediction models, Composite 616 Structures 91(3) (2009) 286-295.

617 [2] A. El-Nemr, Ehab A. Ahmed, B. Benmokrane, Flexural behavior and serviceability of 618 normal-and high-strength concrete beams reinforced with glass fiber-reinforced polymer bars, 619 ACI Structural Journal 110(6) (2013) 1077-1087. 
620 [3] M. Afifi, H. Mohamed, B. Benmokrane, Axial capacity of circular concrete columns 621 reinforced with GFRP bars and spirals, Journal of Composites for Construction 18(1) (2013) 62204013017.

623 [4] American Concrete Institution, Guide for the design and construction of structural 624 concrete reinforced with FRP bars, ACI 440.1R-06, Farmington Hills, MI., (2006).

625 [5] Canadian Standards Association, Design and construction of building components with 626 fiber reinforced polymers, CAN/CSAS806-12, Rexdale, ON, Canada, (2012).

627 [6] American Concrete Institution, Guide for the design and construction of structural 628 concrete reinforced with FRP bars, ACI: 440.1R-15, Farmington Hills, MI., (2015).

629 [7] A. De Luca, F. Matta, A. Nanni, Behavior of full-scale glass fiber-reinforced polymer 630 reinforced concrete columns under axial load, ACI Structural Journal 107(05) (2010) 589-596. 631 [8] H. Tobbi, A.S. Farghaly, B. Benmokrane, Concrete columns reinforced longitudinally and 632 transversally with glass fiber-reinforced polymer bars, ACI Structural Journal 109(4) (2012) $633 \quad 551-558$.

634 [9] H. Karim, M.N. Sheikh, M.N.S. Hadi, Axial load-axial deformation behaviour of circular 635 concrete columns reinforced with GFRP bars and helices, Construction and Building 636 Materials 112 (2016) 1147-1157.

637 [10] D. Cusson, P. Paultre, High-strength concrete columns confined by rectangular ties, 638 Journal of Structural Engineering 120(3) (1994) 783-804.

639 [11] M. Saatcioglu, S.R. Razvi, High-strength concrete columns with square sections under 640 concentric compression, Journal of Structural Engineering 124(12) (1998) 1438-1447.

641 [12] E. Canbay, G. Ozcebe, U. Ersoy, High-strength concrete columns under eccentric load, 642 Journal of Structural Engineering 132(7) (2006) 1052-1060. 
643 [13] H. Tobbi, A.S. Farghaly, B. Benmokrane, Behavior of concentrically loaded fiber-

644 reinforced polymer reinforced concrete columns with varying reinforcement types and ratios,

645 ACI Structural Journal 111(2) (2014) 375-386.

646 [14] H. Mohamed, M. Afifi, B. Benmokrane, Performance evaluation of concrete columns

647 reinforced longitudinally with FRP bars and confined with FRP hoops and spirals under axial 648 load, Journal of Bridge Engineering 19(7) (2014) 04014020.

649 [15] M.Z. Afifi, H.M. Mohamed, B. Benmokrane, Theoretical stress-strain model for circular 650 concrete columns confined by GFRP spirals and hoops, Engineering Structures 102 (2015) $651 \quad 202-213$.

652 [16] M. N.S. Hadi, J. Youssef, Experimental investigation of GFRP-reinforced and GFRP653 encased square concrete specimens under axial and eccentric load, and four-point bending 654 test, Journal of Composites for Construction (2016) 04016020.

655 [17] M. N.S. Hadi, H. Karim, M.N. Sheikh, Experimental investigations on circular concrete 656 columns reinforced with GFRP bars and helices under different loading conditions, Journal of 657 Composites for Construction (2016) 04016009.

658 [18] American Concrete Institution, Building code requirements for structural concrete, ACI: 659 318-14M, Farmington Hills, MI., (2014).

660 [19] Hanson Construction and Building Materials Australia Pty Ltd, 661 http://www.hanson.com.au/, (2016)

662 [20] Australian Standard, Metallic materials-tensile testing at ambient temperature, AS: 1391663 07, Sydney, NSW, Australia, (2007).

664 [21] V-Rod, Composite reinforcing rods technical data sheet, Large Bay SA, Australia, 665 (2012). 
666 [22] International Organization for Standardization, Fibre-reinforced polymer (FRP)

667 reinforcement of concrete: Test methods: Part 1: FRP bars and grids, ISO: 10406-1-05,

668 Switzerland, (2015).

669 [23] American Society for Testing and Materials, Standard test method for tensile properties 670 of fiber reinforced polymer matrix composite bars, ASTM D7205-11, West Conshohocken, 671 PA, (2011).

672 [24] Ganzhou Daye Metallic Fibres Company, WSF Steel Fiber, http://www.gzdymf.com/ 673 product/WSF Steel_Fiber.html, (2015).

674 [25] American Society for Testing and Materials, Standard test method for flexural toughness 675 and first-crack strength of fiber-reinforced concrete (using beam with third-point loading), 676 ASTM C1018-97, (1997) 1-8.

677 [26] S.J. Foster, M.M. Attard, Experimental tests on eccentrically loaded high strength 678 concrete columns, ACI Structural Journal 94(3) (1997) 295-303.

679 [27] P. Paultre, K. Khayat, Y. Langlois, A. Trudel, D. Cusson, Structural performance of 680 some special concretes, Proc., 4th Int. Symp. on the Utilization of High Perf. Concrete, Paris, $681 \quad$ (1996) 787-796.

682 [28] S.J. Foster, J. Liu, S. Sheikh, Cover spalling in HSC columns loaded in concentric 683 compression, Journal of Structural Engineering 124(12) (1998) 1431-1437.

684 [29] P. Paultre, R. Eid, Y. Langlois, Y. Lévesque, Behavior of steel fiber-reinforced high685 strength concrete columns under uniaxial compression, Journal of Structural Engineering 686 136(10) (2010) 1225-1235.

687 [30] S.H. Alsayed, Y.A. Al-Salloum, T.H. Almusallam, M.A. Amjad, Concrete columns 688 reinforced by GFRP rods, 4th Int. Symp. on Fiber-Reinforced Polymer Reinforcement for 689 Reinforced Concrete Structures SP-188, , C. W. Dolan, S. H. Rizkalla, and A. Nanni, eds., 690 American Concrete Institute, Farmington Hills, MI, (1999)103-112. 
691 [31] L.S.M. Hsu, C.T.T. Hsu, Stress-strain behavior of steel-fiber high-strength concrete 692 under compression, ACI Structural Journal 91(4) (1994) 448-457.

693 [32] S. Razvi, R., M. Saatcioglu, Strength and deformability of confined high-strength 694 concrete columns, ACI Structural Journal 91(6) (1994) 678-687.

695 [33] S. Pessiki, A. Pieroni, Axial Load Behavior of large scale spirally reinforced high 696 strength concrete columns, ACI Structural Journal 94(3) (1997).

697 [34] Canadian Standards Association, Design of concrete structures for buildings, CAN/CSA698 A23.3-2014, Rexdale, ON, Canada, (2014).

699 [35] T. Ozbakkaloglu, M. Saatcioglu, Rectangular stress block for high-strength concrete, 700 ACI Structural Journal 101(4) (2004) 475-483.

701

702

703

704

705

706

707

708

709

710

711

712

713

714 
715 List of Tables

716 Table 1: Test matrix

717 Table 2: Mix proportions of the high strength concrete (HSC)

718 Table 3: Mechanical properties of the steel bars

719 Table 4: Mechanical properties of the GFRP bars

720 Table 5: Experimental results of specimens tested under concentric axial load

721 Table 6: Experimental results of specimens tested under eccentric axial load

722 Table 7: Experimental results of specimens tested under four-point loading

723

724

725

726

727

728

729

730

731

732

733

734

735

736

737

738

739

740

Page $\mathbf{3 0}$ of $\mathbf{5 1}$ 


\section{List of Figures}

742 Fig 1: Geometry and reinforcement details of the tested specimens

743 Fig 2: Fabrication of the tested specimens: (a) Alignment of the longitudinal bars; (b)

744 assembling of the reinforcement cages; (c) completed reinforcement cages and (d) completed

745 formwork of the specimens.

746 Fig. 3: Specimen test setup: (a) testing of the column specimens and (b) testing of the beam

747 specimens

748 Fig.4: Typical test setup of: (a) column specimen and (b) beam specimen

749 Fig 5: General behaviour and ductility calculations of the tested specimens

750 Fig. 6: Failure Modes of the column specimens

751 Fig. 7: Close-up view of the buckling of the steel and GFRP longitudinal bars and the rupture 752 of the steel and GFRP helices

753 Fig 8: Close-up view of the crashed region of the beam specimens

754 Fig. 9: Axial load-axial deformation behaviour of the specimens tested under concentric axial 755 load

756 Fig. 10: Axial load-axial deformation and axial load-lateral deformation behaviour of the

757 specimens tested under: (a) $25 \mathrm{~mm}$ eccentric axial load and (b) $50 \mathrm{~mm}$ eccentric axial load 758 Fig. 11: Load-midspan deflection behaviour of the specimens tested under four-point loading

759 Fig. 12: Experimental axial load-bending moment $(P-M)$ interaction diagrams

760 Fig. 13: Comparison of the experimental and analytical axial load-bending moment $(P-M)$

761 interaction diagrams: (a) Group S60; (b) Group G60; (c) Group G60F and (d) Group G30F 
Table 1: Test Matrix

\begin{tabular}{llllll}
\hline Group & Specimen & $\begin{array}{l}\text { Longitudinal } \\
\text { reinforcement }\end{array}$ & $\begin{array}{l}\text { Transverse } \\
\text { reinforcement }\end{array}$ & $\begin{array}{l}\text { Steel fibres } \\
\text { ratio, } \boldsymbol{v}_{\boldsymbol{f}}(\%)\end{array}$ & $\begin{array}{l}\text { Loading } \\
\text { eccentricity (mm) }\end{array}$ \\
\hline \multirow{6}{*}{ S60 } & S60E0 & Steel 6N12 & Steel R10 @ & ---- & 0 \\
& S60E25 & & 60-mm Pitch & & 25 \\
& S60E50 & & & 50 \\
& S60B & & & & Four-point loading \\
G60 & G60E0 & GFRP 6 \#4 & GFRP \#3 @ & ---- & 0 \\
& G60E25 & & 60-mm Pitch & & 25 \\
& G60E50 & & & & 50 \\
& G60B & & & & Four-point loading \\
G60F & G60E0 & GFRP 6 \#4 & GFRP \#3 @ & 1.0 & 0 \\
& G60E25F & & 60-mm Pitch & & 25 \\
& G60E50F & & & & 50 \\
& G60BF & & & & Four-point loading \\
G30F & G30E0F & GFRP 6 \#4 & GFRP \#3 @ & 1.0 & 0 \\
& G30E25F & & 30-mm Pitch & & 25 \\
& G30E50F & & & & 50 \\
& G30BF & & & & Four-point loading \\
\hline
\end{tabular}

768

769

770

771

772

773

774

775

776

777

778

779

780 


\begin{tabular}{lc}
\hline Material & Quantity \\
\hline Cement $\left(\mathrm{kg} / \mathrm{m}^{3}\right)$ & 576 \\
Fine aggregate $\left(\mathrm{kg} / \mathrm{m}^{3}\right)$ & 540 \\
Coarse aggregate $\left(\mathrm{kg} / \mathrm{m}^{3}\right)^{*}$ & 990 \\
Silica fume $\left(\mathrm{kg} / \mathrm{m}^{3}\right)$ & 30 \\
Fly ash $\left(\mathrm{kg} / \mathrm{m}^{3}\right)$ & 64 \\
Water $\left(\mathrm{kg} / \mathrm{m}^{3}\right)$ & 197 \\
Mid-range water reducing admixture $\left(1 / \mathrm{m}^{3}\right)$ & 6 \\
\hline * Maximum size of the aggregate used was $10 \mathrm{~mm}$ &
\end{tabular}

784

785

786

787

788

789

790

791

792

793

794

795

796

797

798

799 
800

801

Table 3: Mechanical properties of the steel bars

\begin{tabular}{cccccc}
\hline $\begin{array}{c}\text { Bar } \\
\text { size }\end{array}$ & $\begin{array}{c}\text { Diameter } \\
\text { of the bar } \\
(\mathrm{mm})\end{array}$ & $\begin{array}{c}\text { Area of } \\
\text { the bar } \\
\left(\mathrm{mm}^{2}\right)\end{array}$ & $\begin{array}{c}\text { Yield tensile } \\
\text { strength } \\
(\mathrm{MPa})\end{array}$ & $\begin{array}{c}\text { Strain corresponding } \\
\text { to tensile strength } \\
(\mathrm{mm} / \mathrm{mm})\end{array}$ & $\begin{array}{c}\text { Elastic } \\
\text { modulus } \\
(\mathrm{GPa})\end{array}$ \\
\hline $\mathrm{R} 10$ & 10 & 78.5 & 420 & 0.0022 & 190 \\
$\mathrm{~N} 12$ & 12 & 113 & 550 & 0.0027 & 200 \\
\hline
\end{tabular}

802

803

804

805

806

807

808

809

810

811

812

813

814

815

816

817

818

819

820

821

Page 34 of 51 


\begin{tabular}{|c|c|c|c|c|c|c|c|}
\hline \multirow{2}{*}{$\begin{array}{l}\text { Bar } \\
\text { size }\end{array}$} & \multicolumn{2}{|c|}{$\begin{array}{l}\text { Diameter of } \\
\text { the bar }(\mathrm{mm})\end{array}$} & \multicolumn{2}{|c|}{$\begin{array}{l}\text { Cross-sectional area } \\
\text { of the bar }\left(\mathrm{mm}^{2}\right)\end{array}$} & \multirow{2}{*}{$\begin{array}{c}\text { Tensile } \\
\text { strength } \\
(\mathrm{MPa})\end{array}$} & \multirow{2}{*}{$\begin{array}{c}\text { Tensile } \\
\text { rupture } \\
\text { strain } \\
(\mathrm{mm} / \mathrm{mm})\end{array}$} & \multirow{2}{*}{$\begin{array}{c}\text { Tensile } \\
\text { modulus } \\
(\mathrm{GPa})\end{array}$} \\
\hline & Nominal & $\begin{array}{c}\text { By } \\
\text { Immersion } \\
\text { test }^{\mathrm{a}} \\
\end{array}$ & Nominal & $\begin{array}{c}\text { By } \\
\text { Immersion } \\
\text { test }^{b}\end{array}$ & & & \\
\hline \#3 & 9.5 & 11 & 70.9 & 95 & 1770 & 0.0231 & 76.8 \\
\hline \#4 & 12.7 & 14.5 & 126.7 & 165 & 1548 & 0.0228 & 67.8 \\
\hline
\end{tabular}

$824{ }^{\text {a }}$ Determined in accordance with the immersion test (ISO 2015) [22]

$825{ }^{\mathrm{b}}$ Calculated based on the diameter of the GFRP bars obtained from the immersion test

826

827

828

829

830

831

832

833

834

835

836

837

838

839

840

841 
Table 5: Experimental results of the specimens tested under concentric axial load

\begin{tabular}{lcccc}
\hline Specimens & S60E0 & G60E0 & G60E0F & G30E0F \\
\hline Yield load $(\mathrm{kN})$ & 2596 & 2603 & 2624 & 2844 \\
Axial deformation at yield load $(\mathrm{mm})$ & 2.7 & 2.9 & 3.1 & 4.2 \\
First peak load $(\mathrm{kN})$ & 2735 & 2721 & 2791 & 2983 \\
Axial deformation at first peak load $(\mathrm{mm})$ & 2.9 & 3.1 & 3.5 & 4.5 \\
Second peak load $(\mathrm{kN})$ & ---- & ---- & ---- & 3272 \\
Axial deformation at second peak load $(\mathrm{mm})$ & ---- & ---- & ---- & 12.6 \\
Ductility & 3.7 & 2.6 & 3.3 & 5.1 \\
\hline
\end{tabular}

843

844

845

846

847

848

849

850

851

852

853

854

855

856

857

858

859 
Table 6: Experimental results of the specimens tested under eccentric axial load

\begin{tabular}{|c|c|c|c|c|c|c|c|c|}
\hline \multirow[b]{2}{*}{ Specimens } & \multicolumn{4}{|c|}{ Loaded under $25 \mathrm{~mm}$ eccentric axial load } & \multicolumn{4}{|c|}{ Loaded under $50 \mathrm{~mm}$ eccentric axial load } \\
\hline & S60E25 & G60E25 & G60E25F & G30E25F & S60E50 & G60E50 & G60E50F & G30E5F \\
\hline Yield load $(\mathrm{kN})$ & 1728 & 1551 & 1728 & 1626 & 1143 & 990 & 1121 & 994 \\
\hline Axial deformation at yield load (mm) & 2.7 & 2.5 & 2.8 & 2.7 & 2.8 & 2.5 & 2.8 & 2.4 \\
\hline First peak load $(\mathrm{kN})$ & 1771 & 1599 & 1793 & 1686 & 1158 & 1023 & 1165 & 1048 \\
\hline Axial deformation at first peak load (mm) & 2.8 & 2.7 & 3.1 & 2.8 & 2.9 & 2.6 & 3.0 & 2.6 \\
\hline Second peak load $(\mathrm{kN})$ & ---- & ---- & ---- & ---- & ---- & ---- & ---- & ---- \\
\hline Axial deformation at second peak load (mm) & ---- & ---- & ---- & ---- & ---- & ---- & ---- & ---- \\
\hline Ductility & 3.5 & 3.4 & 4.2 & 4.9 & 3.4 & 3.8 & 4.3 & 4.6 \\
\hline
\end{tabular}

861

862

863

864

865

866

867

868

869 


\begin{tabular}{lcccc}
\hline Specimen & S60B & G60B & G60BF & G30BF \\
\hline First peak load $(\mathrm{kN})$ & 309 & 321 & 361 & 369 \\
Axial deformation at first peak load (mm) & 7.5 & 6.8 & 7.3 & 7.2 \\
Second peak load (kN) & ---- & 517 & 597 & 696 \\
Axial deformation at second peak load (mm) & ---- & 16.9 & 16.7 & 18.9 \\
Ductility & 4.9 & 5.5 & 5.3 & 7.0 \\
\hline
\end{tabular}

872

873

874

875

876

877

878

879

880

881

882

883

884

885

886

887

888

889

890

891

892 
893
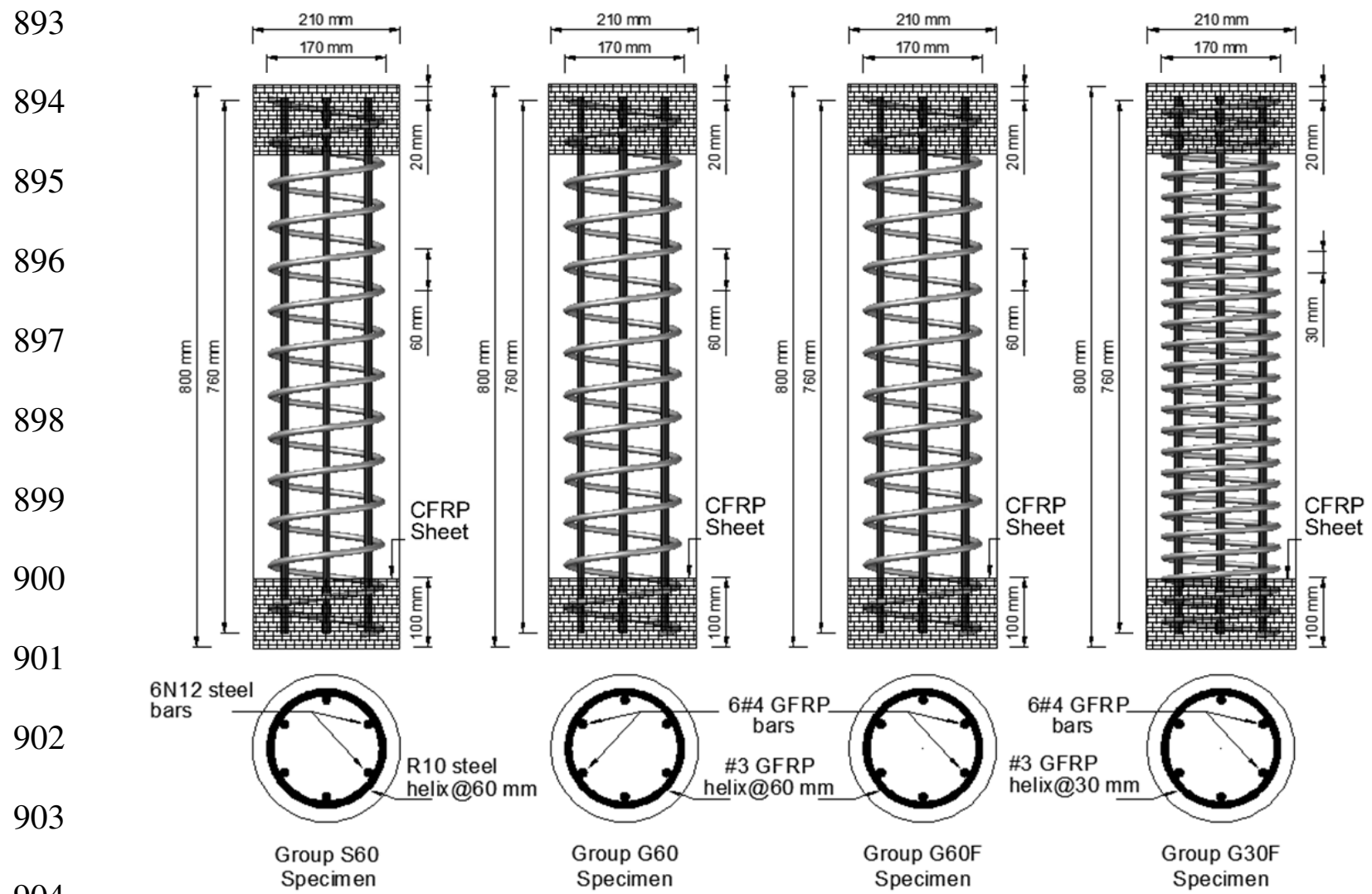

905

Fig. 1: Geometry and reinforcement details of the tested specimens

906

907

908

909

910

911

912

913

914

915

916

917

Page 39 of 51 
918

919

920

921

922

923

924

925

926
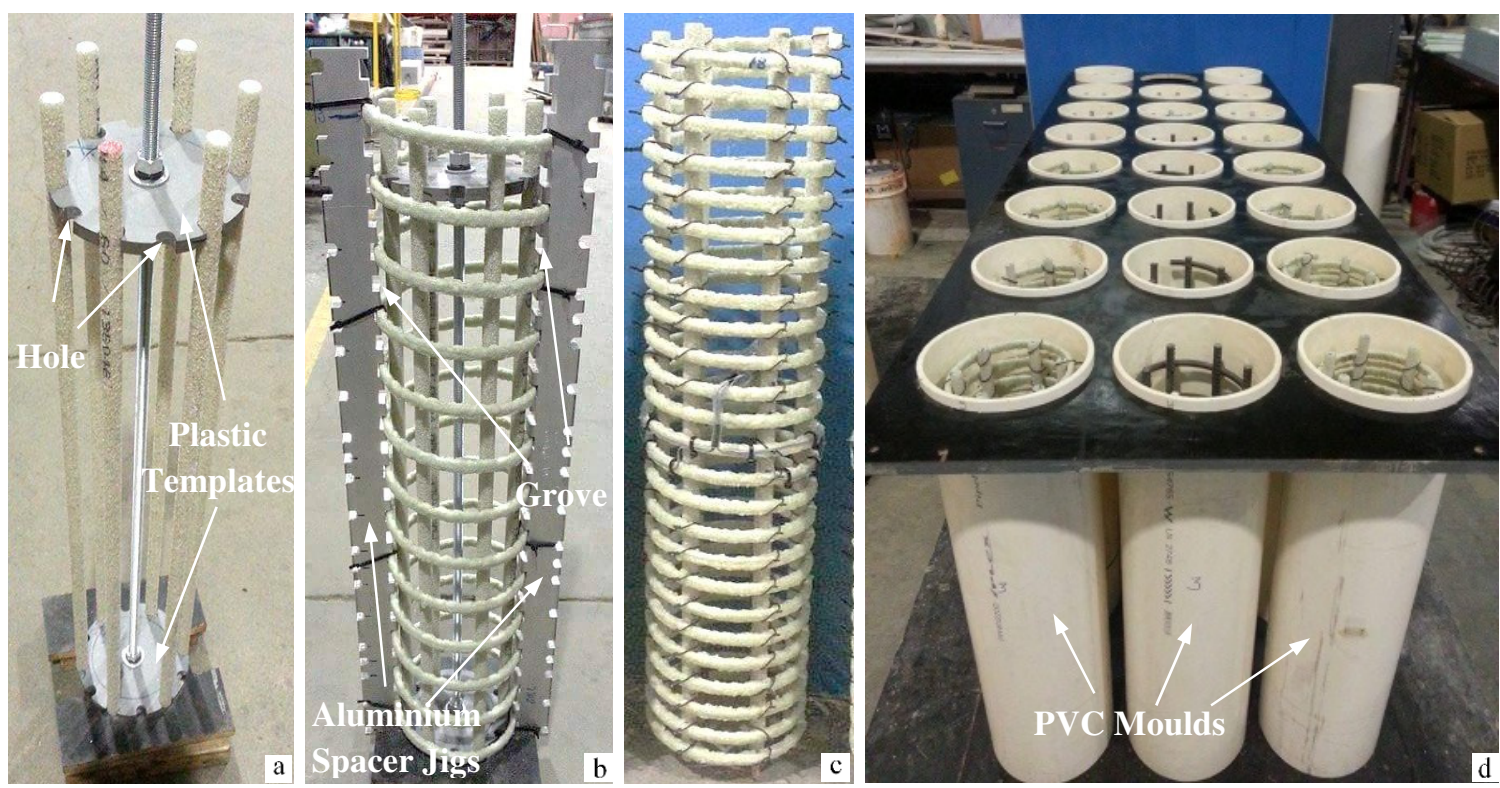

927

Fig. 2: Fabrication of the tested specimens: (a) Alignment of the longitudinal bars; (b)

928

assembling of the reinforcement cages; (c) completed reinforcement cages and (d) completed

929 formwork of the specimens.

930

931

932

933

934

935

936

937

938

939

940

941

942 


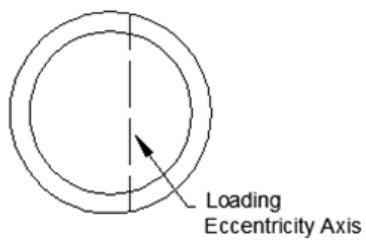

947

Top View

948

949

950

951

952

953

954

955

(a)

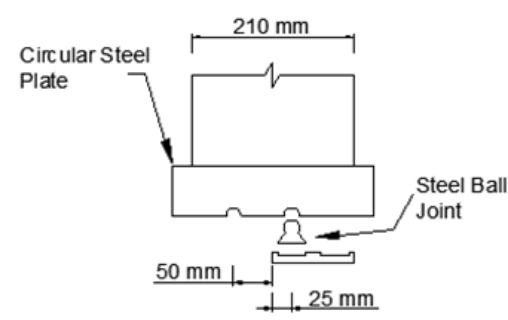

Loading Head

956

957

958

959

960

961

962

963

964

(b)

965

Fig. 3: Specimen test setup: (a) testing of the column specimens and (b) testing of the beam

966 specimens 
968

969

970

971

972

973

974

975

976

977

978

979

980

981

982

983

984

985

986

987

988

989

990

991

992

993

994
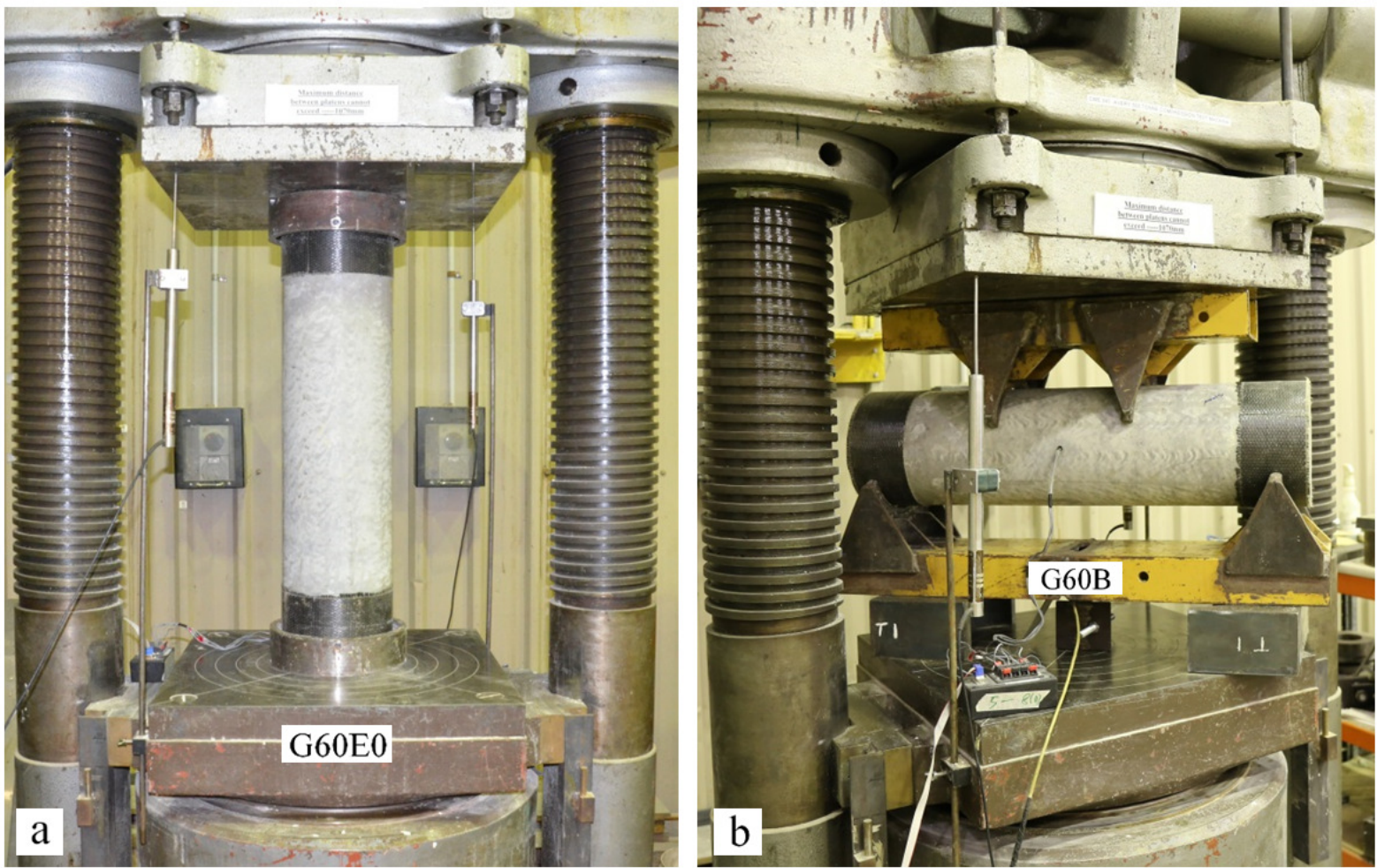

Fig. 4: Typical test setup of: (a) column specimen and (b) beam specimen 
995

996

997

998

999

1000

1001

1002

1003

1004

1005

1006

1007

1008

1009

1010

1011

1012

1013

1014

1015

1016

1017

1018

1019 

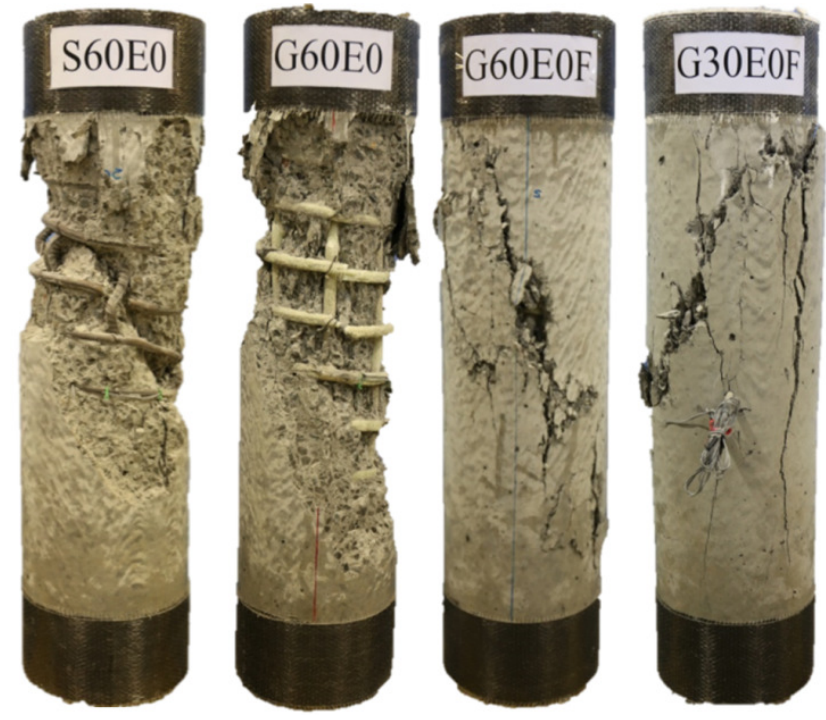

1027

1028

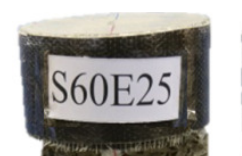

1029

1030

1031

1032

1033

1034
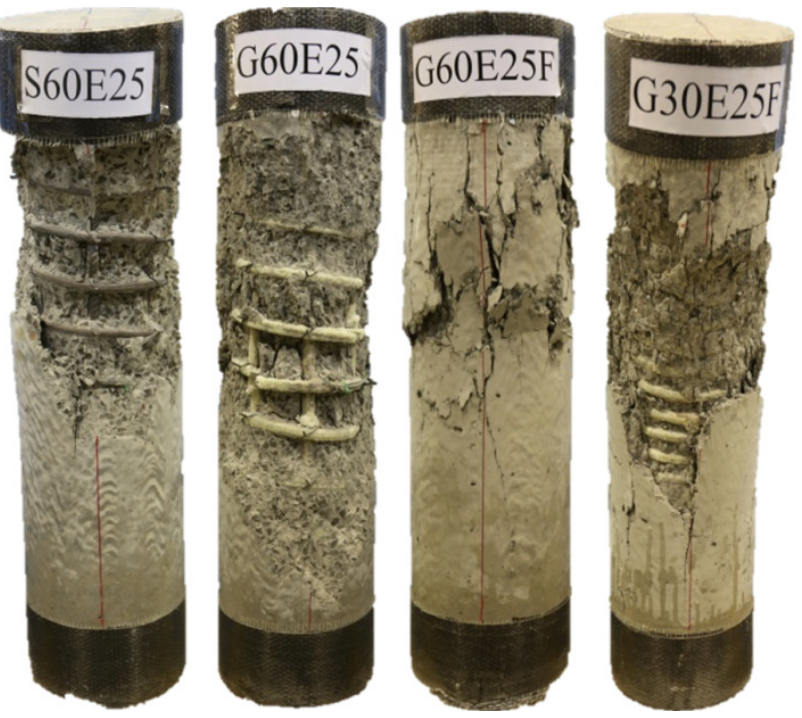

1035

1036

1037

1038

1039

1040

1041

1042

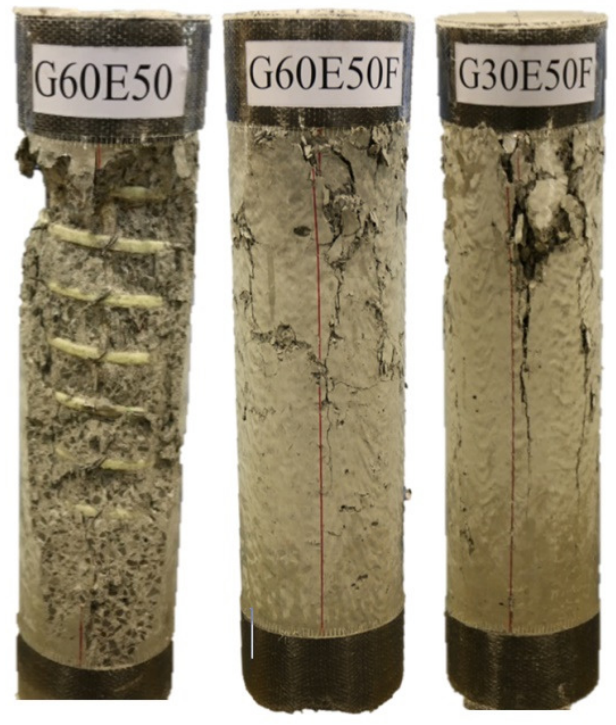

1043

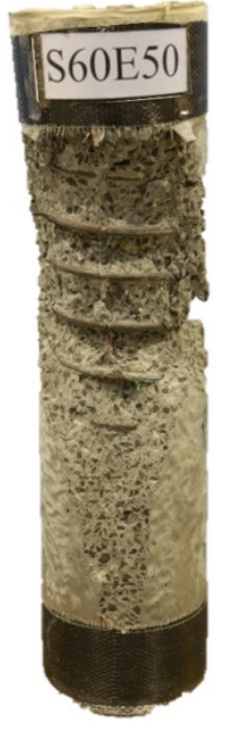

Fig. 6: Failure Modes of the column specimens 
1044

1045

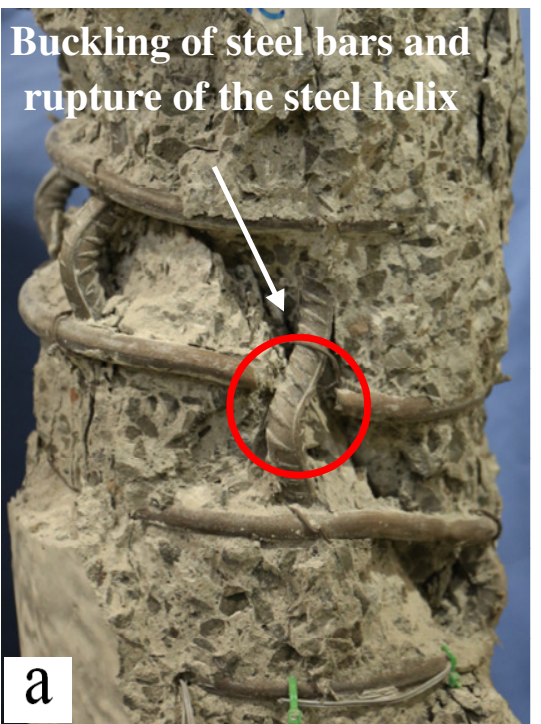

S60E0

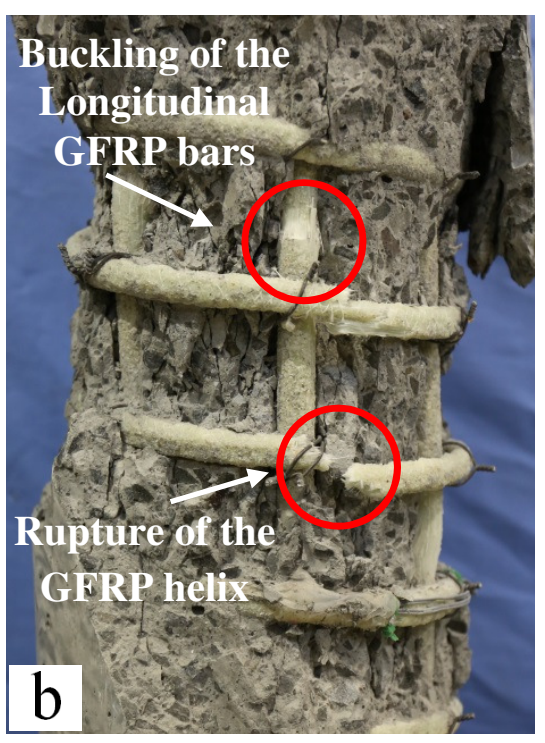

G60E0

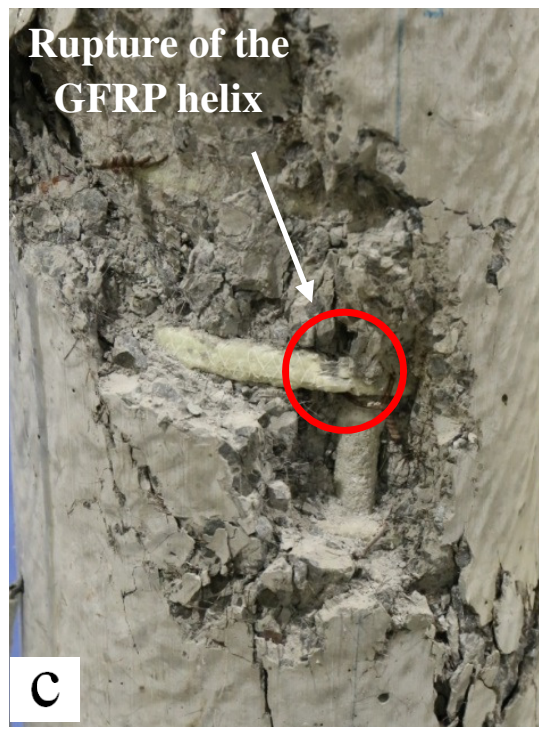

G60E0F

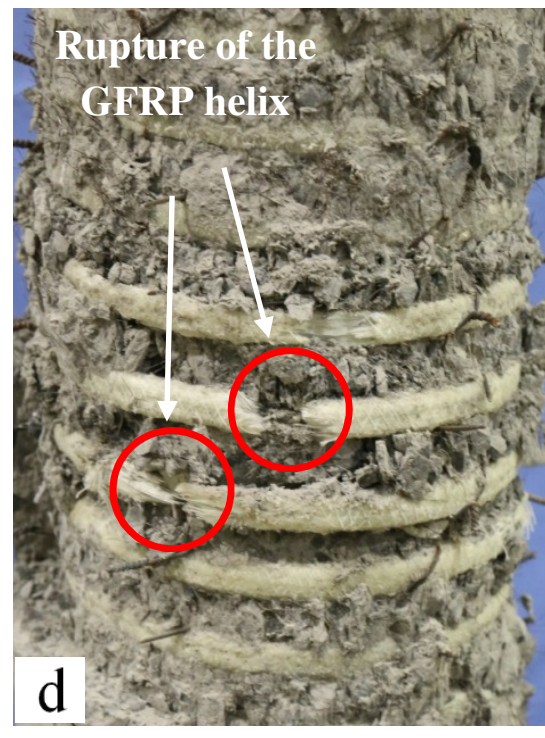

G30E0F

1054

Fig. 7: Close-up view of the buckling of the steel and GFRP longitudinal bars and the rupture of the steel and GFRP helices

1055

1056

1057

1058

1059 
1060

1061

1062

1063

1064

1065

1066

1067

1068

1069

1070

1071
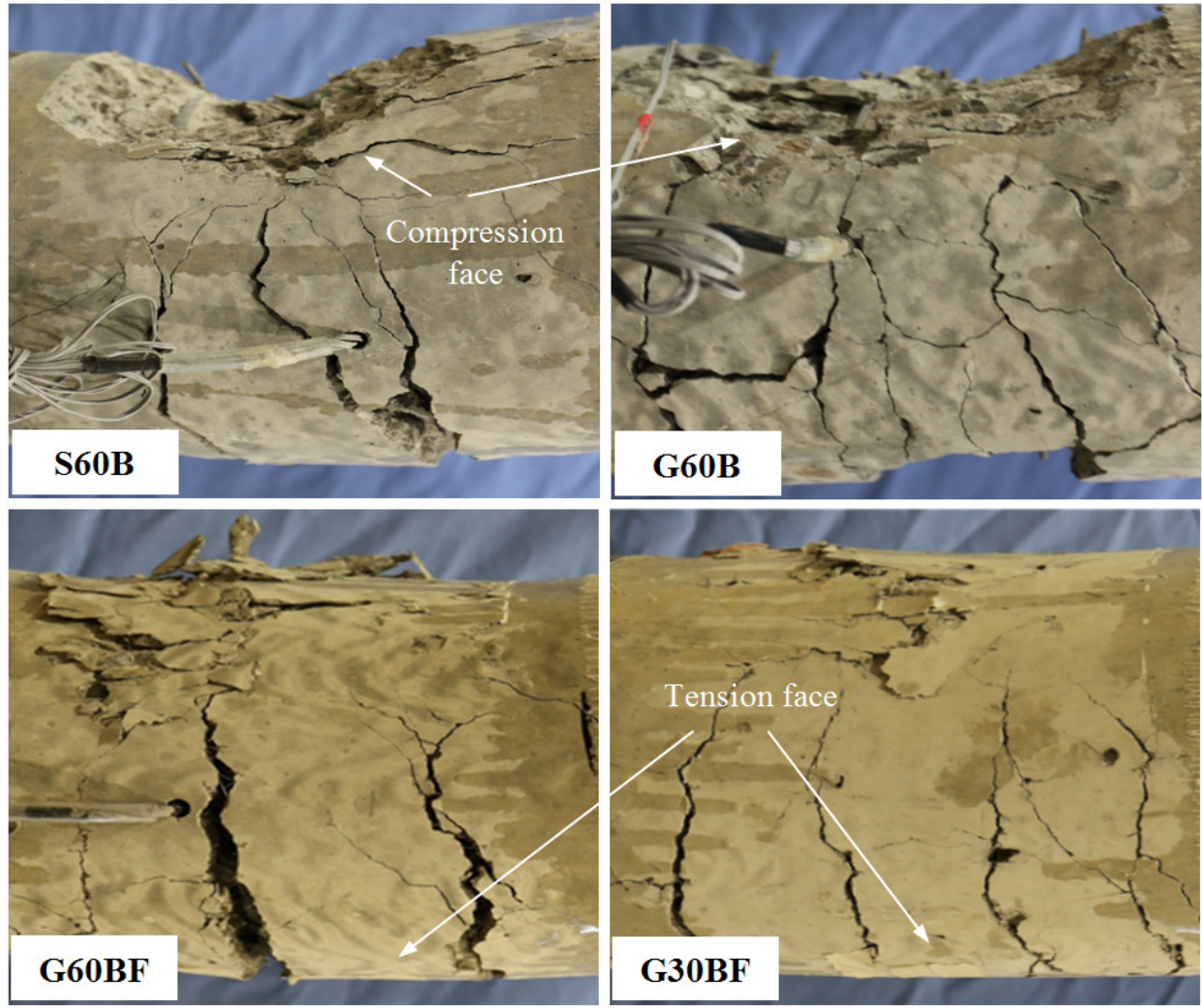

1072

Fig. 8: Close-up view of the crashed region of the beam specimens

1073

1074

1075

1076

1077

1078

1079

1080

1081

1082

1083

1084

Page 46 of 51 
1085

1086

1087

1088

1089

1090

1091

1092

1093

1094

1095

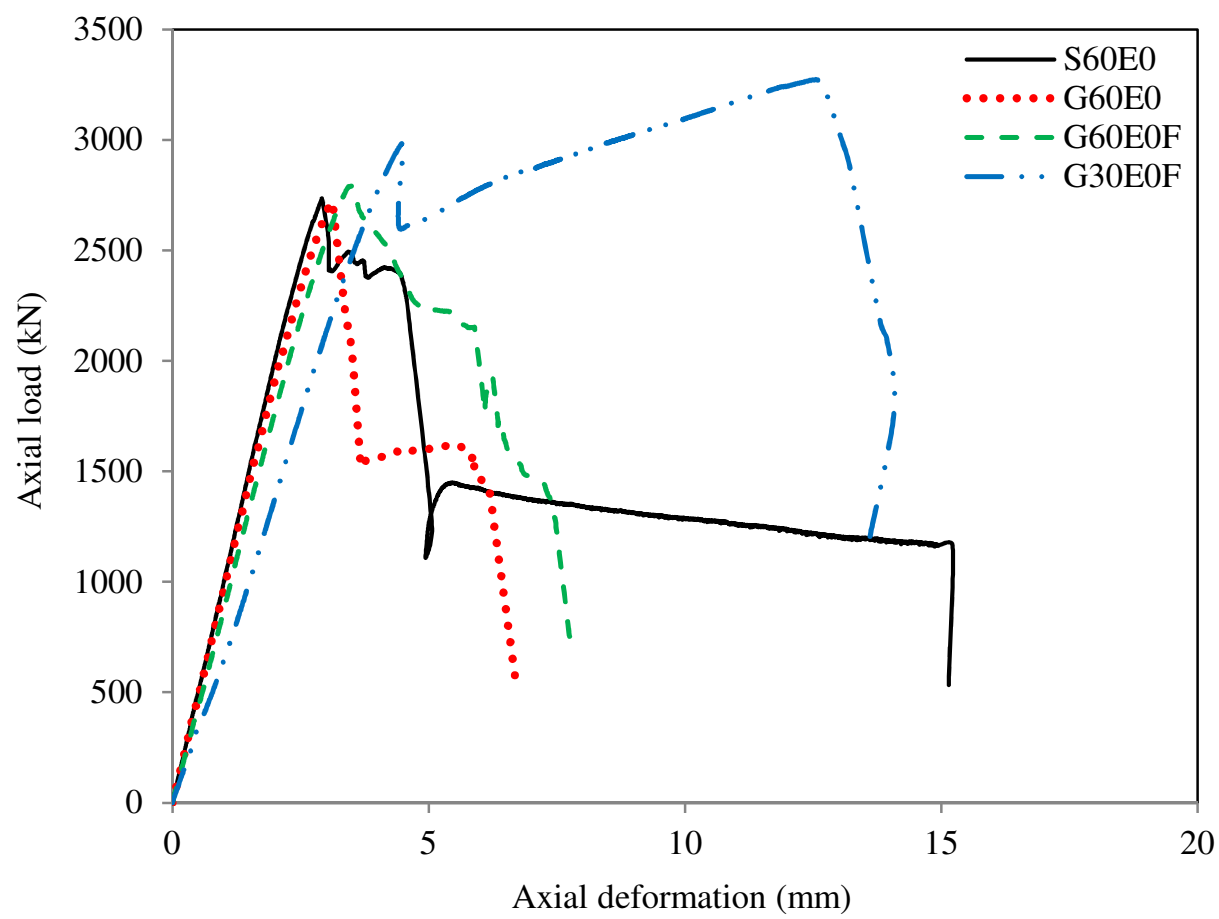

1096

Fig. 9: Axial load-axial deformation behaviour of the specimens tested under concentric axial

1097

load

1098

1099

1100

1101

1102

1103

1104

1105

1106

1107

1108

1109 
1110

1111

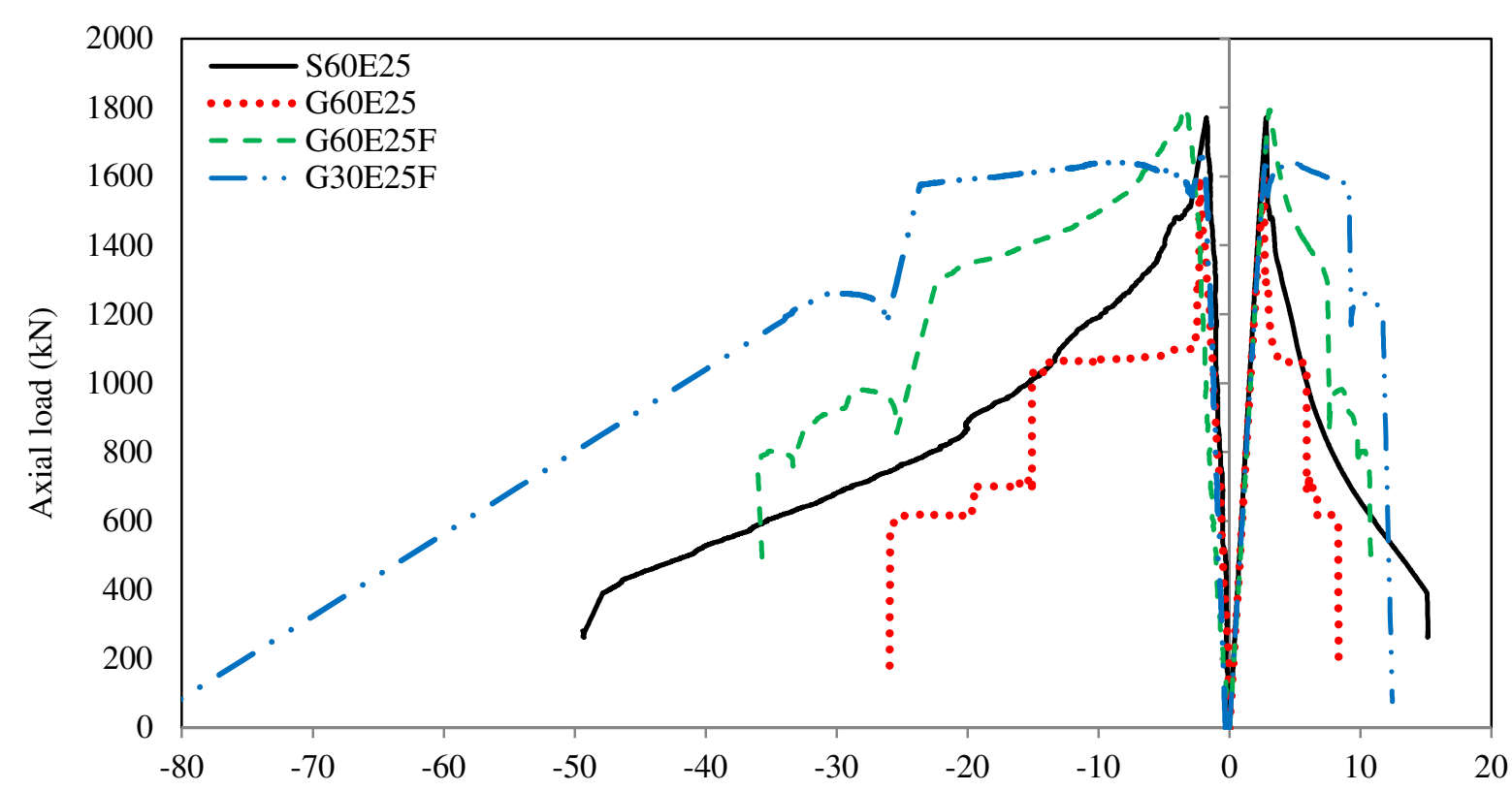

$1119 \quad$ (a)

Lateral deformation (mm)

Axial deformation (mm)

1120

1121

1122

1123

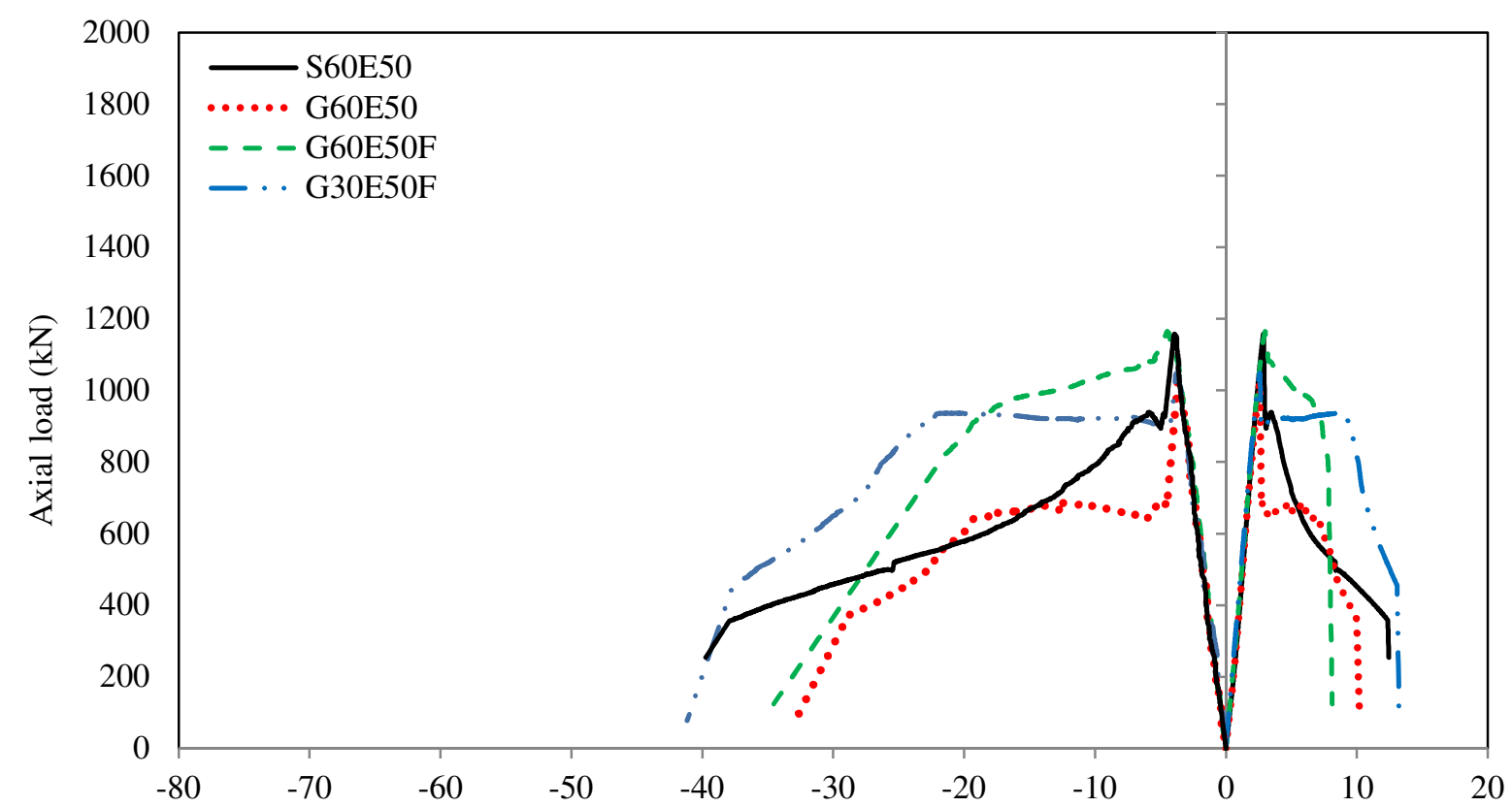

1129

(b)

Lateral deformation (mm)

Axial deformation (mm)

1130

1131 Fig. 10: Axial load-axial deformation and axial load-lateral deformation behaviour of the

1132 specimens tested under: (a) $25 \mathrm{~mm}$ eccentric axial load and (b) $50 \mathrm{~mm}$ eccentric axial load

1133

1134 
1135

1136

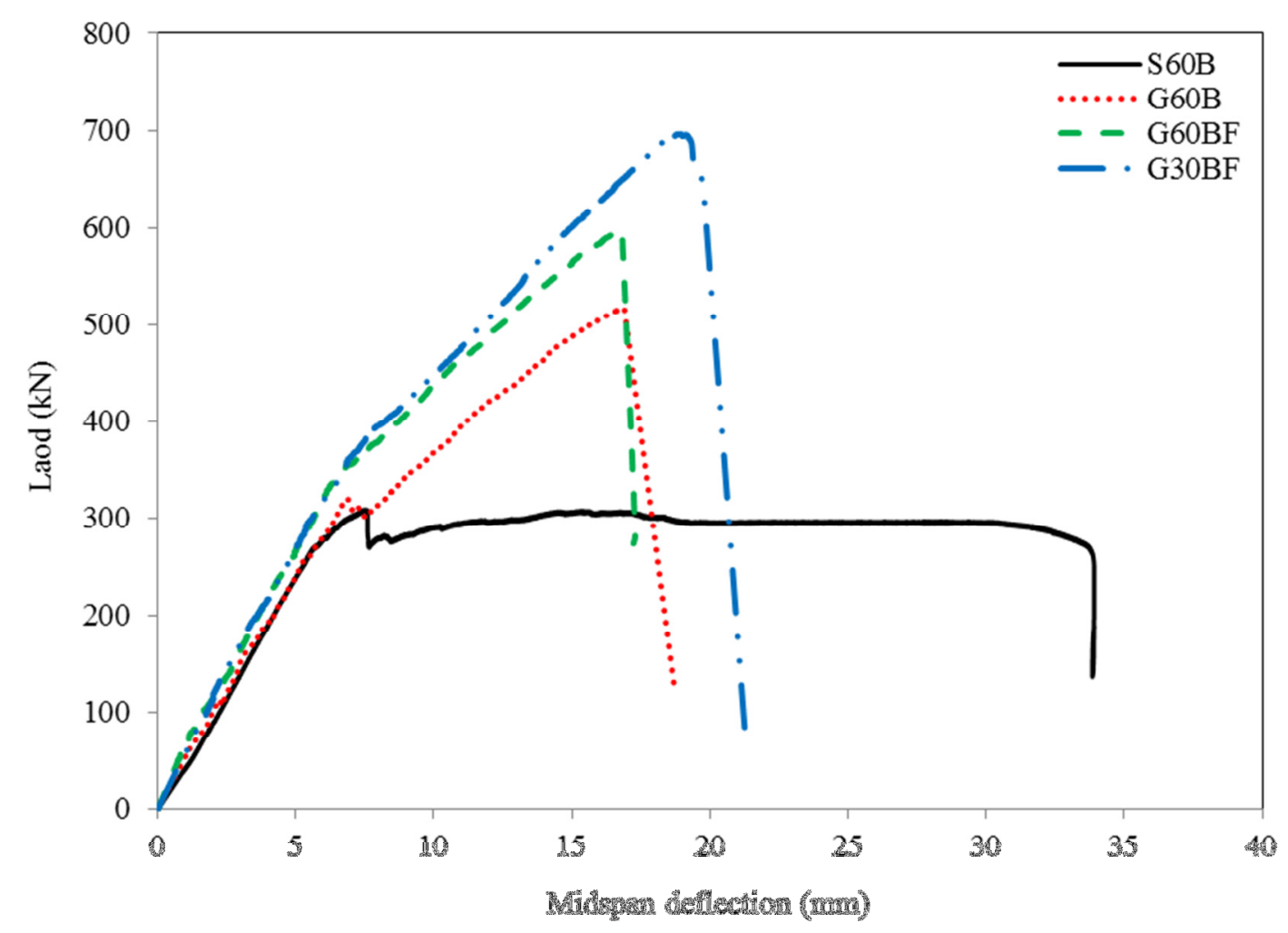

1145

1146

1147 Fig. 11: Load-midspan deflection behaviour of the specimens tested under four-point loading

1148

1149

1150

1151

1152

1153

1154

1155

1156

1157

1158

1159 
1161

1162

1163

1164

1165

1166

1167

1168

1169

1170

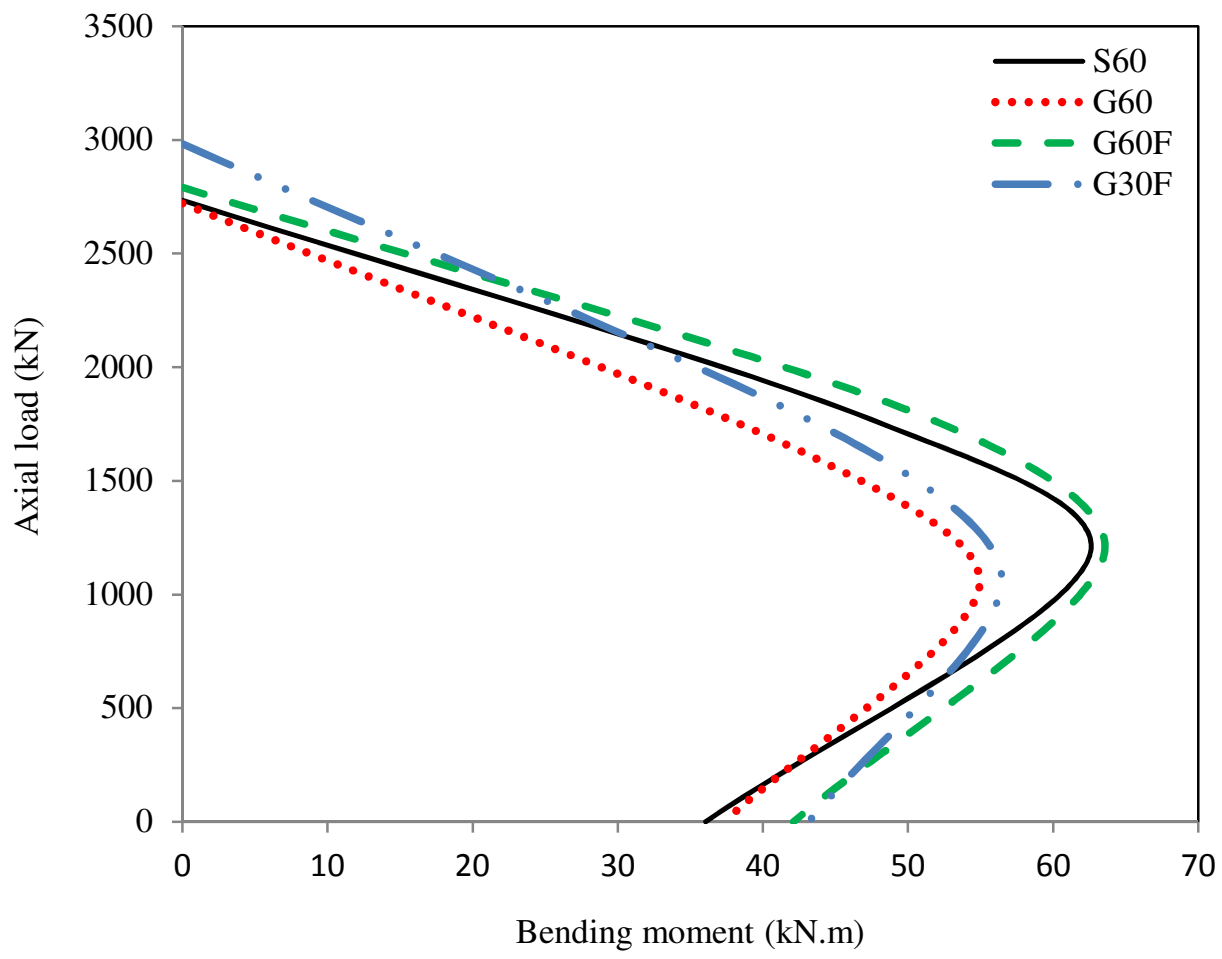

1172

Fig. 12: Experimental axial load-bending moment $(P-M)$ interaction diagrams

1173

1174

1175

1176

1177

1178

1179

1180

1181

1182

1183

1184 

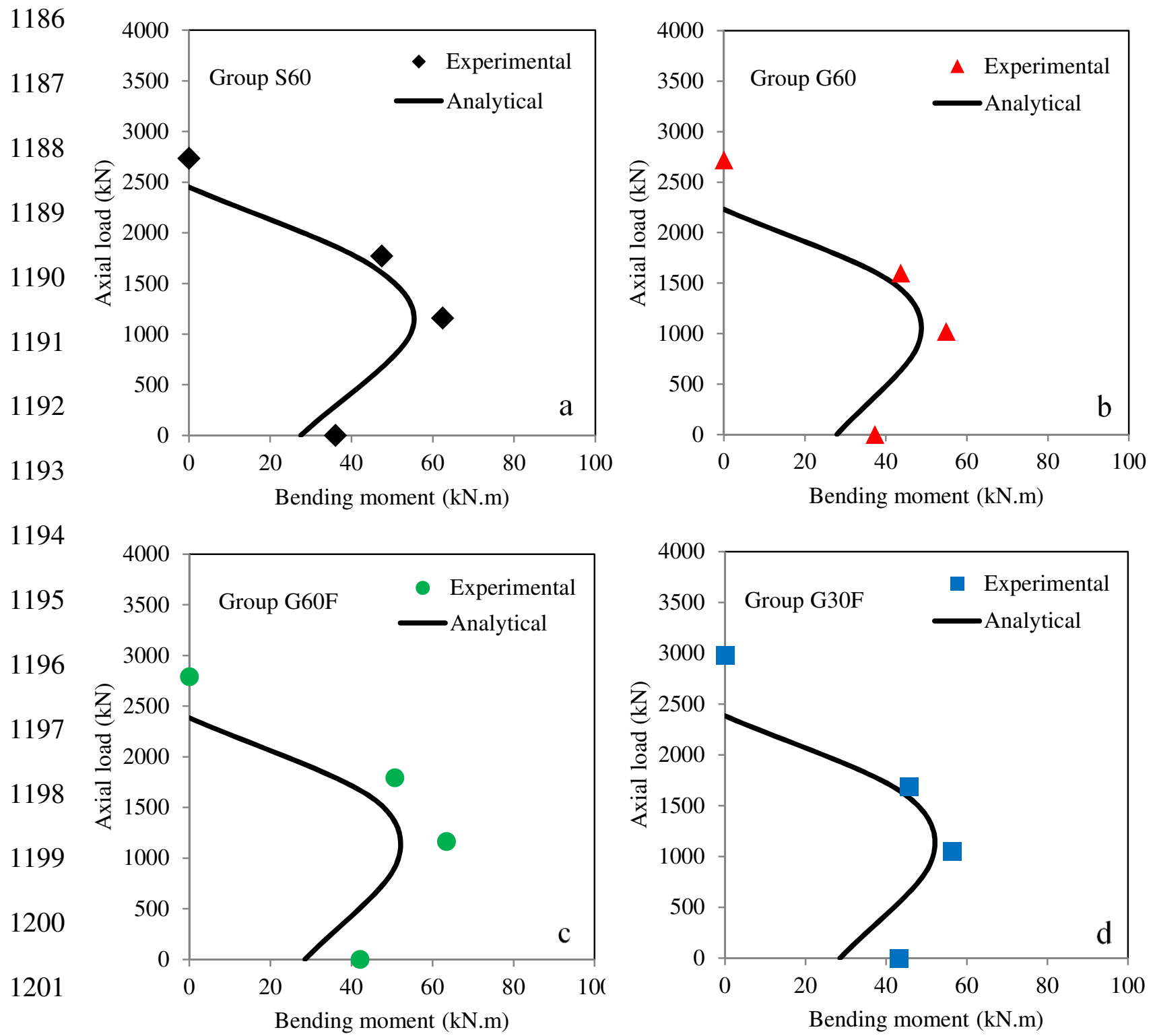

1202

1203 Fig. 13: Comparison of the experimental and analytical axial load-bending moment $(P-M)$

1204 interaction diagrams: (a) Group S60; (b) Group G60; (c) Group G60F and (d) Group G30F

1205

1206

1207

1208 